Article

\title{
Building Sustainability Impacts from the Bottom Up: Identifying Sustainability Impacts throughout a Geotechnical Company
}

\author{
Luke Deamer ${ }^{1,2, *}$, Jacquetta Lee ${ }^{1}$, Mike Mulheron ${ }^{3}\left[\right.$ and James De Waele ${ }^{2}$ \\ 1 Centre for Environment and Sustainability, University of Surrey, Guildford GU2 7XH, UK; j.lee@surrey.ac.uk \\ 2 Keller Group plc, 2nd Floor, 2 Kingdom Street, London W2 6BD, UK; jim.dewaele@keller.com \\ 3 Department of Civil and Environmental Engineering, University of Surrey, Guildford GU2 7XH, UK; \\ m.mulheron@surrey.ac.uk \\ * Correspondence: 1.deamer@surrey.ac.uk
}

Citation: Deamer, L.; Lee, J.; Mulheron, M.; De Waele, J. Building Sustainability Impacts from the Bottom Up: Identifying Sustainability Impacts throughout a Geotechnical Company. Sustainability 2021, 13, 11981. https://doi.org/10.3390/ su132111981

Academic Editor: Fabrizio D'Ascenzo

Received: 1 October 2021

Accepted: 27 October 2021

Published: 29 October 2021

Publisher's Note: MDPI stays neutral with regard to jurisdictional claims in published maps and institutional affiliations.

Copyright: (c) 2021 by the authors. Licensee MDPI, Basel, Switzerland. This article is an open access article distributed under the terms and conditions of the Creative Commons Attribution (CC BY) license (https:/ / creativecommons.org/licenses/by/ $4.0 /)$.

\begin{abstract}
Geotechnical contractors install and repair foundations for buildings and large infrastructure projects. Previously, geotechnical companies have typically focused on sustainability improvements on individual construction projects, with a primary focus on improving the environmental sustainability of site operations. However, the activities of geotechnical companies have sustainability impacts far beyond what they do on site. In the context of the UN Sustainable Development Goals (SDGs), whole company sustainability must also address social and economic sustainability. This paper therefore explores all the processes carried out across a geotechnical company, from human resources through to site operations, assessing their impact against the SDGs using a pedigree matrix approach. Through this investigation, we see that geotechnical companies impact every SDG in some way. There is a strong focus on health and well-being (SDG 4) and economic sustainability (SDG 8) throughout a geotechnical company. Some functions, such as procurement, impact a broad range of SDGs, whilst others, such as HR, mostly only impact social or environmental sustainability. Overall, this approach highlights which processes in each function have the greatest impact on the overall sustainability of the company. It also reveals more sustainability impacts than previous top-down approaches. This means geotechnical contractors can better target sustainability improvements in specific parts of their business, making sustainability relevant to each department. It also aims to empower employees to improve the sustainability of their own day-to-day processes.
\end{abstract}

Keywords: construction; engineering; company; sustainability; SDGs; ESG; geotechnical

\section{Introduction}

Geotechnical companies offer a broad range of subsurface engineering solutions, from ground improvement and piling, to retaining walls and monitoring [1]. Nearly every structure needs some form of foundation or ground improvement. This means geotechnical companies are essential for many construction projects, from building or expanding homes/offices through to constructing and maintaining infrastructure such as roads, tunnels and dams [1,2]. The range of geotechnical solutions offered, materials used and types of construction projects means geotechnical companies have many direct and indirect sustainability impacts to explore.

When it comes to improving the sustainability of geotechnical companies, most previous papers have focused on improving design and site operations. For example, Basu et al. [3] and Pantelidou et al. [4] consider how the design of geotechnical solutions can improve the sustainability of construction projects throughout their life cycle. They both highlight how many environmental sustainability impacts, from materials use to local air quality, are controlled by foundation design and specific site operations. Other papers have taken this a step further, comparing geotechnical solutions to determine which is more environmentally sustainable for different construction projects $[5,6]$. 
However, geotechnical companies face significant challenges when it comes to implementing these design and site sustainability improvements. As specialist subcontractors, geotechnical companies are responsible for the foundations of structures and so exert only limited control on the overall design of construction projects [7]. Furthermore, foundation designs are often stipulated by the client or design consultants [8]. This limits the opportunity of geotechnical companies to input into the design process at an appropriate point; in turn, this limits their ability to optimise the sustainability of the foundations, constraining them to improvements only in the installation process [8]. This is a challenge faced by many other specialist subcontractors in the construction sector [9].

Perhaps more significantly, by concentrating on design and site practices, these previous papers [3-7,9] ignore many of the wider impacts of geotechnical company activities. This includes everything from maintaining equipment and the procurement of materials, through to how they manage their employees. As well as there being other sustainability impacts away from sites, significantly these non-site impacts are not project specific. Given a national geotechnical company will work on hundreds of projects each year [1], improving the sustainability of office- and yard-based processes can have a much longer lasting impact than changes specific to an individual project.

This site-focus in the existing geotechnical literature also extends to social sustainability. Where social sustainability is mentioned at all, it is generally limited to health and safety on site and impacts on the local community, such as from congestion and noise pollution $[2,7,10]$. The limited scope of these papers again means that they may miss social impacts which occur away from site, such as within company human resources or the wider community [11].

Therefore, a key of this paper aim is to capture as many environmental, social and economic sustainability impacts as possible. Critically, this must include those impacts that occur away from project sites, so geotechnical companies can improve their overall sustainability profile.

In this paper, sustainability is defined as "development which meets the needs of current generations without compromising the ability of future generations to meet their own needs" [12]. More specifically, the UN Sustainable Development Goals (SDGs) are used to illustrate how geotechnical companies impact the triple bottom line of sustainability. The 17 SDGs were agreed by every UN member country in 2015, with countries aiming to reach them by 2030 [13]. Although initially aimed at whole countries to achieve, the SDGs have increasingly been used by individual companies to report on their sustainability activities [14]. Through the lens of company reporting frameworks, such as GRI [15] and the SDG Compass [16], the SDGs have become a common language for geotechnical companies and their stakeholders to communicate their sustainability priorities [14]. Using the SDGs also enables this paper to capture the environmental, social and economic sustainability impacts of geotechnical companies; this contrasts with other approaches, mentioned previously, that limit their focus to environmental impacts on sites [3-7,9].

To capture sustainability impacts beyond site operations, this paper breaks down geotechnical company impacts by business function. A business function is defined as part of an organisation that deals with a particular shared area of work [17], such as human resources (HR) or finance. As well as better detailing the overall sustainability of geotechnical companies, a key aim of this approach is to identify how each part of the company impacts the different aspects of sustainability. By removing the artificial construct that sustainability can only be seen as relevant to individual projects, it helps each business function focus on the areas of sustainability they can control and impact.

Another key aim of this paper is to establish the key processes that result in the sustainability impacts of each function. A process is a series of actions, taken by a business function, to achieve a particular result [17], such as recruitment in HR or concrete testing in site operations. These processes can then be grouped to give the overall sustainability of each business function. This process-based, bottom-up, sustainability assessment means sustainability impacts are linked to specific processes. This approach also highlights the 
specific processes across geotechnical companies that are responsible for the greatest environmental, social and economic sustainability impacts. In turn, this means that business functions can target individual processes when looking to improve their sustainability. Unlike top-down company assessments $[2,3,10,11]$, this approach also ensures that relatively small impacts, potentially only arising from only one or two processes, can still be captured.

This paper applies the approach outlined above to a single geotechnical company, with the aim of capturing the sustainability impacts resulting from each individual company process. Keller Ltd., the UK subsidiary of the Keller Group, is used as a case study for this investigation, with business functions and processes divided according to this company's structure. Keller Group is the world's largest specialist geotechnical contractor, offering the investigation a wide range of developed geotechnical processes [1]. Importantly, Keller is also primarily a geotechnical contractor. This means it is easier to isolate and assess the processes of this specific subsector, rather than including those related to other sectors of the construction industry. It is worth emphasising the approach used, and many of the challenges identified, are intentionally applicable to many geotechnical companies and the wider construction sector.

In summary, the research objectives are therefore:

- To determine the sustainability impacts of an entire geotechnical company

- To establish which functions and processes in a geotechnical company are responsible for key sustainability impacts.

- To highlight good sustainability practices in each geotechnical business function.

These objectives are purposefully designed to support geotechnical companies as they look to assess and improve their sustainability. In order to achieve these objectives, this paper presents a case study of a geotechnical company principally using document analysis. The methodology and methods are outlined first. Following this section, the results and discussions begin with a comparison of geotechnical company structures; this aims to demonstrate the applicability of this research to other companies. An overview of the sustainability impacts of a whole geotechnical company is then presented. From there, the sustainability impacts of each business function is explored in turn, with key processes picked out to demonstrate the range of impacts. This is then brought together with the practical and theoretical conclusions of the paper.

\section{Methodology and Methods}

\subsection{Methodology}

Since processes in a geotechnical company are constantly evolving, this paper is part of wider active research [18]. The case study approach used in this paper is therefore typical of active research $[18,19]$. Focus is placed on ensuring research outputs are applicable, practical and actionable for geotechnical contractors. Grounded theory was therefore chosen to see how these themes and approaches emerge from the analysis of geotechnical companies [18]. Therefore, the function structure to this paper is grounded in the existing structure of a geotechnical company. Likewise, the sustainability assessments are related directly to company reporting on the UN SDGs. The resulting model is intended to promote the many ways that the company can improve sustainability, encouraging employees to develop their own initiatives that are important to them.

\subsection{Detailed Methods}

Before defining the sustainability impacts of business functions, it is important to define the responsibilities of each business function in a geotechnical company. The existing company structure of Keller is broadly used to determine the business functions and group processes. The largest functions with the most processes were further broken down to allow for more granular analysis. To explore whether these research findings are transferable to other geotechnical organisations, this paper compares the structures of three alternative geotechnical companies. These company structures are compared based 
on their organisational charts, or 'organigrams'; this is a common method for company mapping and comparisons [20,21].

Each process is allocated to one of the identified business functions. This allocation is based on which function owns the particular process. Companies like Keller already divide their process documentation by business function, so this is a relatively simple step. Most processes can be captured from multiple sources, such as published procedures, method statements, policies and forms.

Each process identified is scored against every SDG using a pedigree matrix (see Appendix A). This is a straightforward method to assess qualitative data, standardising the requirements for each SDG [22]. Whilst originally targeted at countries, the SDGs here are interpreted as global sustainability topics for companies to achieve by 2030 [13]. This interpretation of the SDGs is consistent with many listed companies [14], with organisations such as the SDG Compass [16] and GRI [15] applying the SDGs to companies. Russell et al. [9] and Goubran [23] have also demonstrated the value of this approach to the overall construction sector.

Processes in the pedigree matrix are allocated a score from -1 to 5 for each SDG. The exact category definitions are specific to each SDG, but broadly:

- $-1=$ Negative impact on that SDG, or impacted but not recorded

- $0=$ No impact on that SDG

- $1=$ Minimum reporting on that SDG

- 2 = Reactive ways to minimise negative impacts on that SDG

- 3 = Proactive ways to minimise negative impacts on that SDG

- $4=$ Actively improves that SDG

- 5 = Innovative best practice, actively improving that SDG

The method for scoring a process starts at 0 and works upwards until the process no longer fits the matrix description. Only if a process impacts that SDG, but does not fulfil the criteria for a 1 , is it allocated a -1 . This approach particularly aims to highlight sustainability best practices; the 5 positive scores differentiate how well processes impact an SDG, whilst negative impacts are grouped as -1 . Again this approach is consistent with other pedigree matrix approaches [22]. After trialling more negative categories, it was decided that the minimal requirements of a 1 , needing only the recording or reporting of the sustainability impacts, removed the need for more negative scoring differentiation.

A more quantitative approach was considered, using metrics for each SDG rather than using the qualitative pedigree matrix approach adopted here. However, a key challenge of a more quantitative approach is a lack of available data. Beyond fuel, material and basic HR data, sustainability reporting is not common in geotechnical companies. Likewise, whilst considerable work has been done in producing SDG metrics that are relevant to companies, rather than countries [14-16], at a process level there remains a significant allocation challenge. For example, how much of a geotechnical company's gender pay gap should be the responsibility of HR recruitment processes, relative to their development programme? In addition, there are some indirect sustainability impacts that would not be captured using existing quantitative metrics. For example, fatigue management processes are primarily aimed at ensuring employee health \& well-being (SDG 3), but they also impact on project quality and economic performance (SDG 8) as well as the risk of environmental accidents (SDG 15). Regardless, as more consistent, wide-ranging and process-specific sustainability metrics become available, it is possible to integrate them into the pedigree matrix approach adopted here.

Nvivo software was used to record the parts of processes that impact each SDG, whilst the scores for each process was recorded in an Excel spreadsheet. The spreadsheet was then used for all data analysis, including calculating function averages, maximum and minimum scores, intermodal ranges and further data analysis. Individual processes were then picked out as examples using pivot tables.

Any scores that were unclear following the document analysis were raised with key stakeholders in the respective functions. These narrative discussions with key stakeholders 
helped clarify and confirm the scores for specific processes. Such an approach is commonly used in active case study research to ensure the accuracy of the scoring [18,19].

The data presented in this study is not publicly available since the processes are proprietary to Keller ltd. Nonetheless, the pedigree matrix used in the study is available in the Appendix A. This allows anyone to carry out the same assessment of any other geotechnical company and compare results/conclusions.

\section{Results \& Discussion}

\subsection{Geotechnical Contractor Structure}

Organisational charts, or 'organigrams', can be used to explore the business functions represented in a geotechnical company [20,21]. Alongside the functions used in this research, the functions of 2 other (anonymised) geotechnical companies are presented for comparison (Figure 1).

\begin{tabular}{|c|c|c|c|}
\hline Paper & Keller & Geotech Y & Geotech Z \\
\hline Finance & Finance & Finance & Finance \\
\hline IT & IT & Centralised IT & IT \\
\hline \multirow[t]{3}{*}{$H R$} & HR & HR & $\mathrm{HR}$ \\
\hline & & Centralised HSE & HSE \\
\hline & & & $\begin{array}{l}\text { Quality \& business } \\
\text { improvement }\end{array}$ \\
\hline Procurement & Procurement & Purchasing & Procurement \\
\hline Design Eng. \& site & \multirow{2}{*}{$E \& O$} & Contracts Eng. & Tech. \& design \\
\hline Yard operations & & Construction & Operations \\
\hline \multirow{2}{*}{$\begin{array}{c}\text { Estimating and } \\
\text { Marketing \& Strategy }\end{array}$} & Estimating & Estimating & Pre-construction \\
\hline & Marketing \& Strategy & & $\begin{array}{l}\text { Business development \& } \\
\text { contracting }\end{array}$ \\
\hline
\end{tabular}

Figure 1. A comparison between the company functions used in this paper and the functions of Keller and two anonymised geotechnical companies. Functions are ordered and colour coded to highlight similar functions.

Figure 1 demonstrates that there is similarity between geotechnical companies in terms of their business functions. Key functions, such as finance, HR and IT, are common across all the companies. There are also common functions for procurement and health, safety, environment (and quality) (HSEQ) that appear under different names.

Note that geotechnical company $Y$ is part of a larger main contractor. This means that some of its functions, such as IT and HSEQ, are centralised within the main contractor organisation. However, since Keller and geotechnical company $\mathrm{Z}$ both have these business functions, this paper captures these functions. Clearly, the structure of three geotechnical companies structures should not be used to infer every geotechnical company has the same functions. However, the appearance of significant commonality suggests the approach adopted may be applicable to other geotechnical companies.

For the purposes of this investigation, the strong link between design engineering and site operations means these two business functions are grouped together. Design engineering has many impacts on site processes. For example, the specification of a design directly controls the type, size, position and number of piles which are installed on site; this has indirect impacts on equipment used and time spent on site. Therefore, this grouping 
aims to highlight the indirect impacts of design decisions and help view site operations through the lens of design constraints.

Yard operations, where equipment is made, maintained, and repaired, is also often grouped under engineering and operations. However, whilst these yard processes are impacted by site activity, they remain a separate, independently controlled set of processes. Yards processes also have some critical differences to site work, including having a permanent working space and more regular working hours. Therefore, in this paper, yard operations are separated from engineering and operations.

\subsection{Sustainability Impact Overview}

Before considering the individual business functions, it is important to look at the overall impacts of a whole geotechnical company. To help geotechnical companies focus their efforts to improve sustainability, functions are compared in terms of their influence on the SDGs. A simple way to do this is to assess where each function impacts the SDGs, irrespective of how positive or negative these impacts are (Figure 2). This is achieved by recording the percentage of processes in each function receiving a score $\neq 0$, since 0 indicates no impact on that SDG. Percentages are used to allow the comparison between business functions, since some functions have far more documented processes than others.
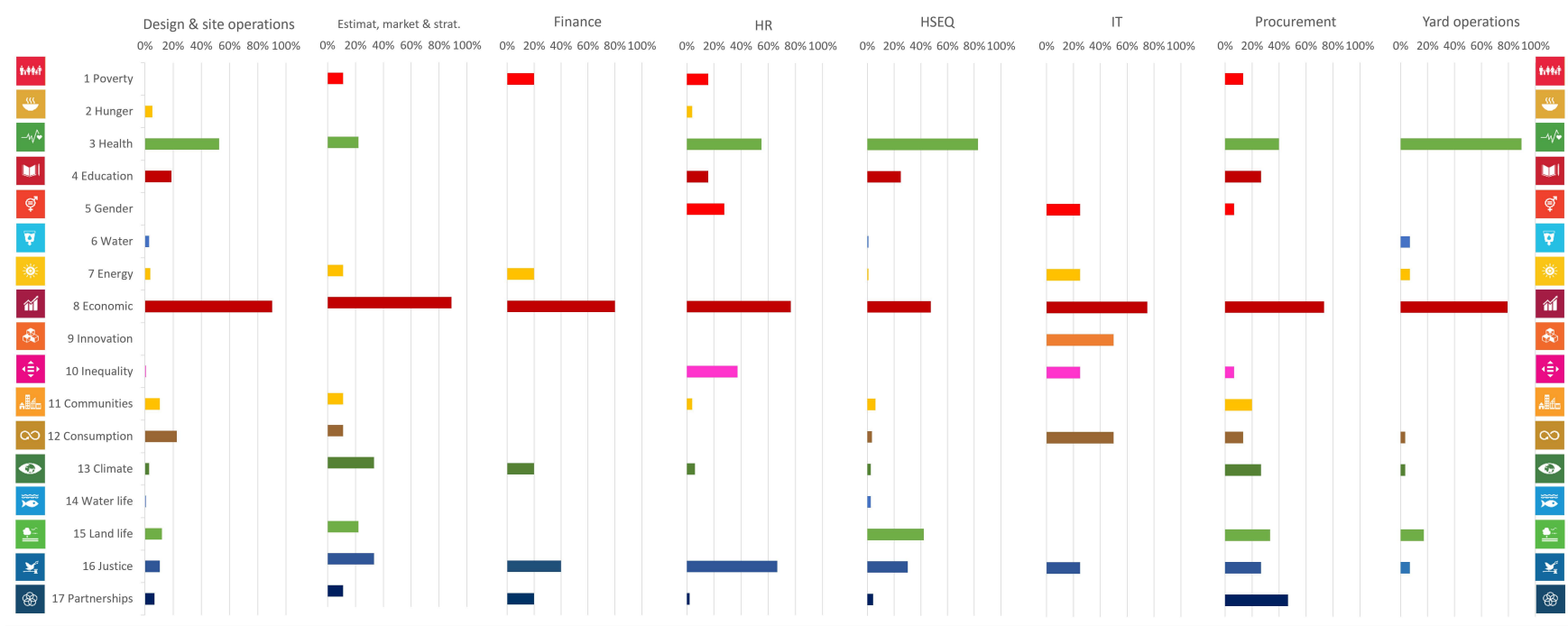

Figure 2. The proportion of processes in each function that impact the SDGs in some way. For each function, the larger the bar, the more processes impact that SDG. Functions are arranged in alphabetical order along, whilst SDGs are listed in numerical order down the Y axis. HR is Human Resources; HSEQ is Health, Safety, Environment \& Quality; IT is Information Technology.

Figure 2 illustrates that a geotechnical company impacts every SDG in some way. For example, zero hunger (SDG 2), which is not commonly associated with geotechnical projects in the literature, is impacted by specific HR processes such as subsistence allowances on site and site facilities management. Whilst the magnitude of these impacts is not always large, this shows there are processes across the company that, in combination, impact all the SDGs.

Figure 2 also highlights a number of similarities between business functions. For example, almost all functions have processes that look to guarantee product quality and the profitability of the company (SDG 8). Likewise, a large proportion of processes have an impact on employee health and well-being (SDG 3). This likely reflects Keller's need to meet health and safety legal requirements, as well as the associated commercial benefits of having employees that can identify hazards and manage the associated risks to ensure smooth running of projects. 
In relation to social sustainability, however, some functions appear to have more of an impact than others. HR is the main contributor to improving SDGs such as no poverty (SDG 1), inequality (SDG 10) and gender equality (SDG 5). Perhaps more surprisingly, social impacts also come out in procurement. For example, procurement particularly looks at ensuring the supply chain have minimum processes in place to tackle modern slavery and promote equity, diversity and inclusion.

With respect to environmental sustainability, HSEQ, Operations and Procurement have a role to play, with Life on land (SDG 15), climate action (SDG13) and responsible consumption and production (SDG 12) of materials all impacted by these business functions. Responsible consumption and production (SDG 12) is also impacted by design and engineering functions. The focus on SDG 12 within the IT business function reflects the small number of processes in that function (see Section 3.10).

Figure 2 also highlights sustainability gaps, where geotechnical companies have fewer impacts. As noted previously, only a few business functions impact on zero hunger (SDG 2), with only processes like subsistence allowances and basic welfare requirements making a contribution. Other SDGs with fewer impacts, like life below water (SDG 14), simply reflect the fact Keller Ltd. tends to work on land, rather than on marine projects. The absence of many processes impacting water use (SDG 6) may seem more surprising, with only a few site and yard operations contributing towards this area of sustainability. This points to all the water use of a geotechnical company being controlled by a small number of key processes, rather than being embedded in many different processes.

As well as looking at the overall company impacts, it is useful to consider how well different processes impact each SDG (Figure 3). A process receives a score for its impact on each separate SDG using the pedigree matrix; this means one process has 17 scores, one for each SDG. Figure 3 clearly shows the most common score is 0 , with no impact on that SDG. This reflects that most processes identified only impact one or two specific SDGs, so the remaining SDGs receive a score of 0 . However, a small number of processes impacted significantly more SDGs; for example, the procurement supplier approval process impacts 11 different SDGs.

Just 8 processes recorded scores of $=1$ for one or more SDGs, meaning there were only a few negative sustainability impacts that went completely unreported. Where impacts were recorded, most processes focused on simply reporting (score of 1 ) or reducing negative impacts (scores of $2 \& 3$ ), rather than actively having a positive impact (score of 4 or 5). It is interesting to note that proactive approaches to minimise harm (scores of 3 ) are slightly more common than just reactive methods to minimise harm (score of 2).

Good health and well-being (SDG 3) and decent work and economic growth (SDG 8) both stand out in Figure 3; these are the only two SDGs where more processes impact them (score of 1-5) than have no impact (score of 0 ). Immediately this highlights that these two SDGs have been consciously recorded and built into key processes. However, although they are impacted by more processes, they otherwise follow a similar trend to the other SDGs.

The overall trend in Figure 3 suggests geotechnical companies are more likely to simply report on sustainability impacts, rather than improving them. Nonetheless, where actions are taken to minimise negative impacts, proactive approaches (score of 3) are more common than reactive approaches (score of 2). This suggests a certain maturity to minimising negative sustainability impacts, even if this positive engagement has not yet translated into more positive impacts (scores of 4 and 5). 


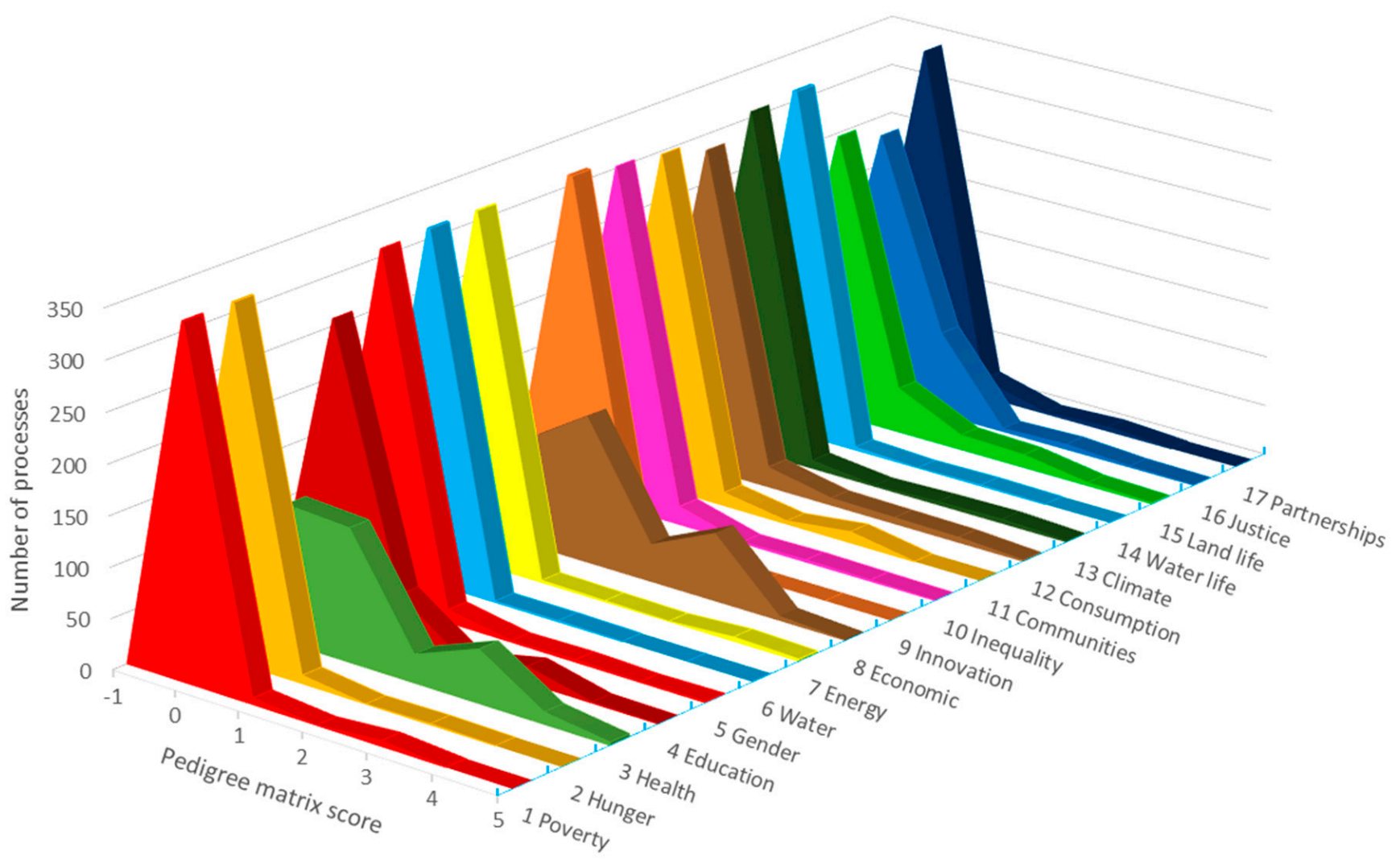

Figure 3. The scores for every SDG across all 364 analysed processes. For more on scoring, see the detailed methods.

The difference in the trends for health (SDG 3) and economic sustainability (SDG 8) compared to the other SDGs may reflect a greater effort to identify and tackle impacts on these two areas of sustainability across all company processes. In part, this may be because Keller, like many geotechnical companies, works to ISO 45001 health and safety management standards and ISO 9001 quality management standards. These standards require proactive identification and mitigation of health and safety and quality risks. However, it may also reflect other drivers, such as client demand for certain requirements or even employee demand prioritising these areas of sustainability.

\subsection{Interpreting the Box and Whisker Plots}

By considering each business function in isolation, it becomes possible to identify where specific sustainability impacts occur within a geotechnical company. To assist with this analysis, for each function, the maximum and minimum score for each SDG, as well as the interquartile range and average, is displayed in a box and whisker plot (Figures 4-11). For each SDG, the "whisker" lines indicate the minimum and maximum score, the "box" is drawn between the 25th and 75th interquartile score and a dot records the mean process score. This gives an indication of the best and worst scoring impacts in a function, as well as the general impacts of processes in the function. Note where the interquartile ranges are shown as 0 , this indicates that at least $50 \%$ of the processes in the function do not impact that specific SDG. Beyond these box and whisker plots, individual processes are then highlighted where they have large impacts on specific areas of sustainability.

\subsection{Design Engineering and Site Operations}

Design and site operations are two interlinked functions. Since many site operation processes are decided at the design stage, it makes sense to address these two functions together. For example, whilst the direct impacts of a design office are relatively small, the influence they have over the sustainability of site operations and overall geotechnical 
projects is significant. This is reflected in the broad range of SDG impacts in Figure 4, with at least one process impacting 14 of the 17 SDGs.

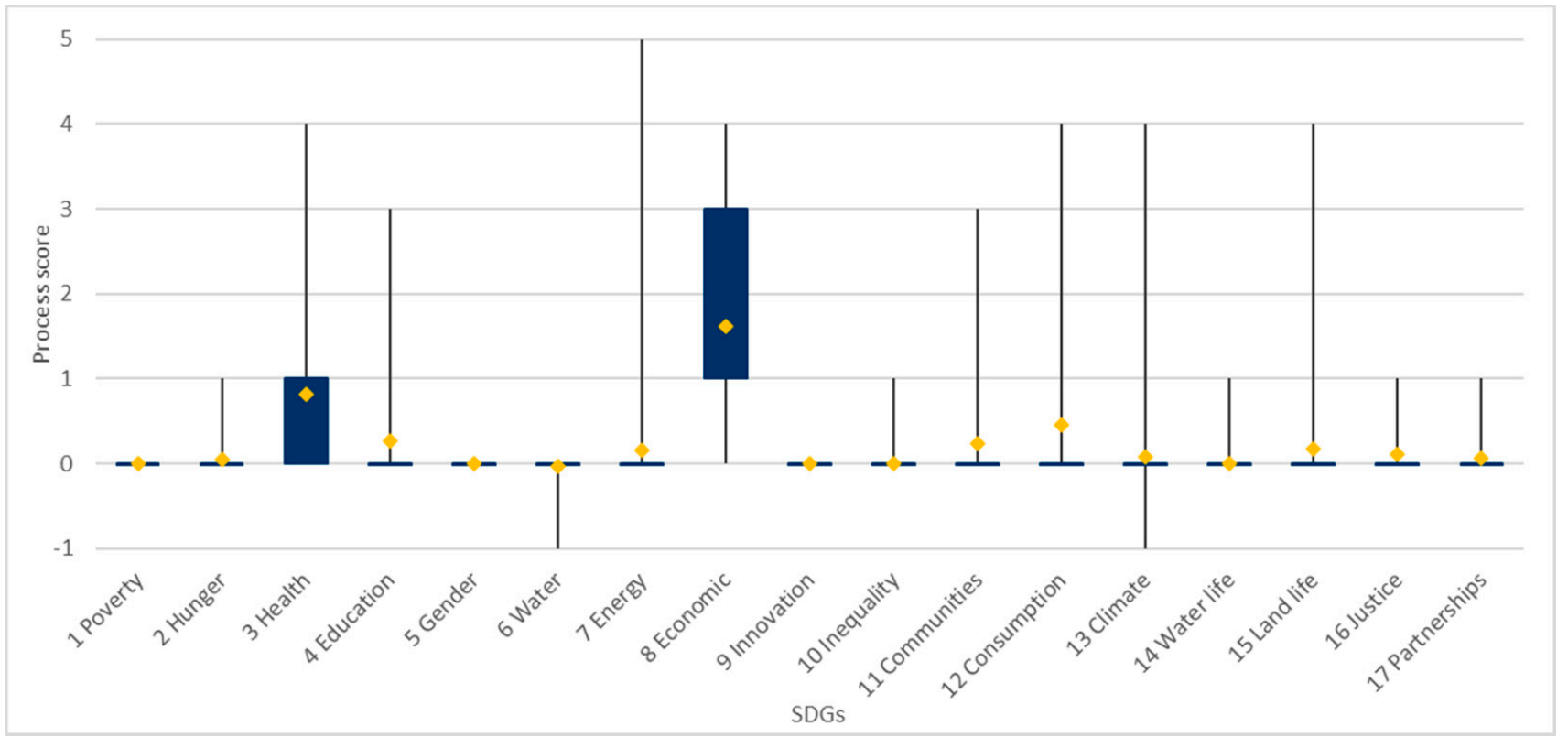

Figure 4. Design engineering and site operations box and whisker plot.

As the interquartile ranges show in Figure 4, there is a particularly strong focus in almost all the processes on ensuring proactive economic sustainability and work quality (SDG 8), as well as proactive and reactive ways to minimise harm to employees (SDG 3). These are common impacts across many of the project-focused business functions. From a design perspective, this means designing for quality and health and safety on site (SDGs $3 \& 8$ ). For example, health and safety risk mitigation is built into site plans and work package plans at the design stage.

The average scores for the other 15 SDGs are between 0 and 1 , meaning most processes have no impact, or only report, on these areas of sustainability (Figure 4). This reflects the large number of different processes carried out in this function, with 133 recorded in total. However, individual design engineering processes still have a positive impact on specific areas of sustainability. For example, multiple ground/building monitoring processes are powered solely by solar panels, receiving a score a 5 for clean energy (SDG 7) for minimising energy use. Other positive impacts came from the testing and loading capacity procedures; this load information is fed back into designs, reducing the chance of over-engineering and decreasing materials required for future piles (SDG 12).

Design processes are also critical to determining the type of foundations, as well as the number and size of piles/ground improvement. This means many design processes control the raw material use (SDG 12), waste to landfill (SDG 12), embodied carbon (SDG 13), climate resilience (SDG 13), cost and quality (SDG 8) of the foundations. For example, a driven piling solution can be used to avoid producing waste spoil (SDG 12), whilst ground improvement can be used to reduce the need for foundations made of cement and steel, reducing the embodied carbon for a project (SDG 13) $[5,6]$.

However, despite factoring in these environmental priorities into some overarching design decisions, there is a lack of consistent reporting on embodied carbon of materials (SDG 13) in key design processes. This explains the negative SDG scores in the design stage, where impacts are not captured or negative impacts occur (scores of -1 in Figure 4). For example, there is an unrecorded trade-off on some grouting processes; 'environmental' bulk fill grouts are chosen for creating less dust, but multiple databases (e.g., [24,25]) 
indicate this material has a higher embodied carbon than the materials used for normal bulk fill grout.

In terms of site operations, a significant number of decisions affecting sustainability are made in the design stages before site work begins. Nonetheless, site operations are directly responsible for many site environmental sustainability impacts. A lot of this focuses on resource use and waste spoil production (SDG 12). Whilst there is minimal reporting on resource use, good testing and loading capacity processes does help minimise excess resource use and ensure project quality and resilience. Individual geotechnical solutions, such as ground improvement, scored better for SDG 12, reducing the need for concrete and steel; in the case of vibro stone columns, a process noted that recycled aggregate could also be used to reduce raw material use and encourage closed loop thinking and practice.

As with design engineering, there is a particular focus on avoiding, but reporting, both health \& safety and environmental incidences on site (SDGs 3 \& 15). Many processes, from drilling plans and delivery instructions to equipment maintenance, therefore have risk assessments and mitigation steps built in, resulting in scores of 2 or 3 in Figure 4 . There are also examples of technology being used to avoid over-exposure to hazards; for example, the use of hand-arm vibration monitoring, worn on the wrist, helps mitigate employees risk of developing 'white finger' or other vibration injuries. These wrist monitors can also be charged from solar panels on the container, requiring no grid or generator electricity and therefore eliminating indirect scope 2 emissions (SDG 7).

Site operations is also the only function, aside from HR, that impacts local communities, towns and cities (SDG 11). Impacts range from direct emissions, such as generating and suppressing dust and noise on site, to creating congestion and particulate emissions transporting rigs and equipment on to site. Again, specific processes tend to identify and try to mitigate these impacts; for example, some set-up processes set out how equipment can be baffled to reduce noise. Other processes detail how rigs should be delivered outside of rush hour commuting times and avoid populated areas where possible.

However, away from the company's fixed installations, no processes try to actively improve relationships with the local community, with the highest scoring process only looking to minimise harm (Figure 4). This may reflect the limited time geotechnical companies spend on site; since geotechnical companies are mostly tier 2 subcontractors and are only on site for the initial part of a project, they are less likely to engage with the main contractor on project-length community engagement [9].

\subsection{Health, Safety, Environment \& Quality (HSEQ)}

HSEQ is a function that supports site planning, operations and audits. The broad range of solutions, forms and audits they assist with means that there are 118 different processes recorded under HSEQ. As expected, HSEQ impacts on employee health \& wellbeing (SDG 3), decent work and quality (SDG 8) and life on land (SDG 15). This is reflected in Figure 5; with over 50\% of processes impacting these SDGs in some way, these are the only SDGs to have an interquartile range above 0. Legal compliance (SDG 16) and training/development of employees (SDG 5) are also commonly incorporated into many of the processes. From toolbox talks to mandatory training and assessment (e.g., Construction Skills Certification Scheme [26]), this focus on training means many processes are proactive in either minimising harm or having a positive impact. 


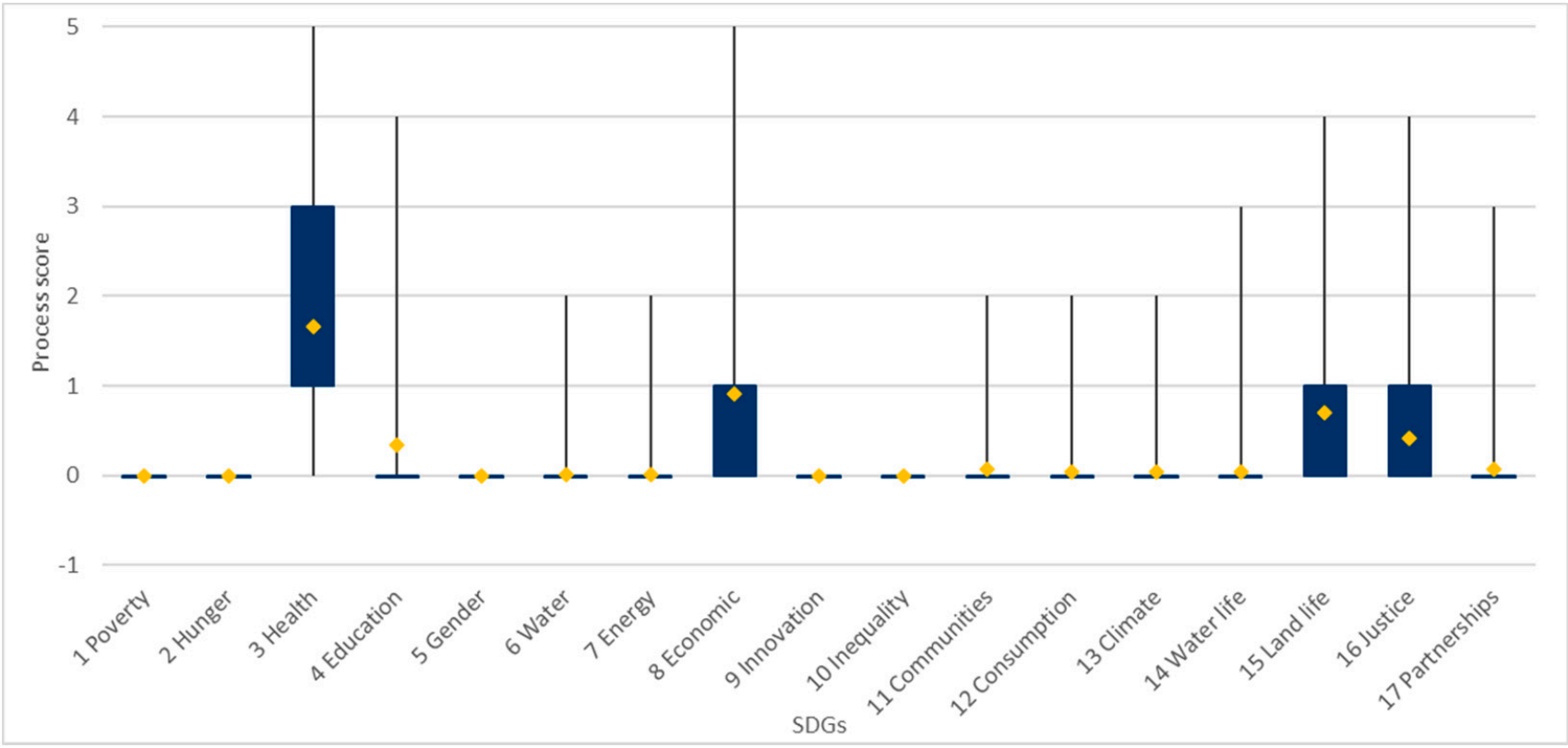

Figure 5. HSEQ box and whisker plot.

On SDGs such as resource use (SDG 12), and dust and noise (SDG 11), most HSEQ processes only passively monitor the impact of geotechnical sites/yard operations (score of 1 in Figure 5). For example, spoil production and concrete use are only reported when required by clients for BREEAM [27], LEED [28] or other environmental reporting requirements.

When it comes to investigating safety (SDG 3) and environmental (SDG 15) accidents, the majority of processes are based around reactive ways to minimise harm (score of 2). The best example of this are accident procedures that record accidents and near-misses; although best described as reactive, these follow a pre-planned process to ensure root cause analysis is carried out and mitigations are put in place to proactively ensure these events do not happen again. These processes are essential for geotechnical companies to ensure environmental and health \& safety accidents are not repeated. However, more proactive approaches are always encouraged before accidents occur. This is why risk assessments are built in to all site and yard procedures as standard (score of 3). Leadership site safety visits and frequent reminders that employees can stop work when they don't feel safe are both good examples of proactive ways to drive accident reduction.

Most HSEQ processes score a 3 or less, focusing on reducing negative impacts on the SDGs, rather than actively improving them. Nonetheless, a small number of HSEQ processes actively improve sustainability. For example, mental health programmes and support, like those provided by charities like Mates in Mind [29], are invaluable for employee well-being; these associated processes not only looking to reduce poor mental health and it's impacts, but they have also been shown to increase general well-being and even productivity [30]. Similarly, safety days, where new employees spend a day in immersive site-focused theatre, help employees understand the real risks of poor safety (SDG 3), as well as helping them learn how to deescalate situations on site (SDG 3).

The HSEQ function also manages 'step forward' or continuous improvement proposals, which encourage employees to come up with ideas to improve health \& safety, reduce cost or improve the environmental sustainability of processes. With an associated reward and recognition scheme in place for the best ideas, this has led to incremental improvements in many areas of sustainability, from economic productivity (SDG 8) to safety (SDG 3) and carbon (SDG 13). For example, one implemented proposal devised a way to rearrange equipment on delivery trucks; this reduced the number of trucks needed to mobilise from three to two. This offered a financial saving, reducing the number of 
trucks and fuel needed to set up a site, as well as reducing transport emissions and local site traffic.

Finally, in terms of economic sustainability, various lean-focused processes look to proactively improve productivity and efficiency in all operations (SDG 8). Rather than just passively monitoring progress, this positive and proactive approach earns the score of 5 (Figure 5). One recent lean innovation saw the use of containers to help equipment fit onto two trucks rather than three; this saved truck hire costs, reducing congestion onto and off of site and reducing transport emissions.

\subsection{Yard Operations}

Yard operations primarily focus on making and maintaining equipment that is then used on site. This means the 33 yard processes are varied, ranging from welding to painting, maintaining rig engines to concrete hose inspection and cleaning. This also means cost and quality control (SDG 8) is built into over half of all yard processes (see interquartile range in Figure 6), before the equipment is used on site. Quality control ranges from the documented visual inspection of equipment like hoses and rigs, to rigorous pressure system tests by certified individuals (score of 3). Alongside inspections, this quality focus is built into yard process designs; for example, when welding auger drill bits, the designs specifically focus on reducing wear on the equipment, reducing the risk of delays and damage on site (SDG 8).

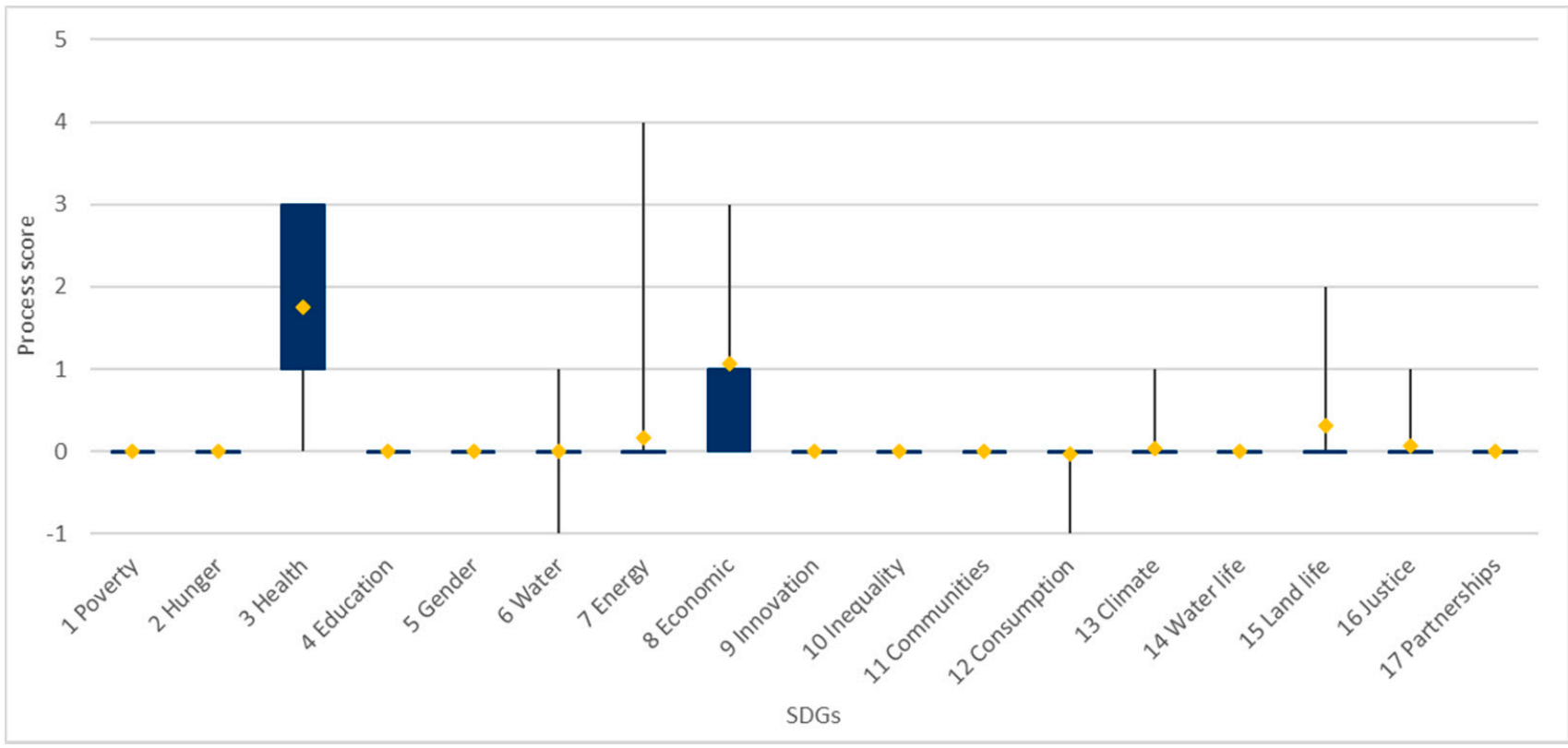

Figure 6. Yard operations box and whisker plot.

Operations in a geotechnical yard have a variety of environmental impacts (Figure 6), with processes using water (SDG 6) and materials like steel, oil and paint (SDG 12). As a consequence, it is important that documented processes capture this material and water use to support continuous improvements in practice. For example, whilst waste wood and steel are commonly segregated for recycling, the volumes of each waste stream are not routinely recorded and so remain unknown. Where glass, paper, cardboard, plastics, food, and aluminium are collected into the general waste stream, the potential for reuse or recycling is disrupted. Similarly, not recording the source and volume of water used for cleaning equipment and other processes hinders steps to reduce water consumption and reliance. Such issues are reflected in the negative scores for these two SDGs in Figure 6.

Following current trends on site, yard processes actively manage energy use through the use of electric motors rather than relying on diesel engines; when coupled with a green 
energy tariff, this offers an energy and carbon saving (SDG 7). For example, all forklift trucks are powered by rechargeable battery charged by mains electricity. The score of 4 for clean energy (SDG 7 in Figure 6) comes from the operation and maintenance of solar panels, which help power part of the yard. Beyond these examples though, few processes look to actively decrease energy use; instead, whole yard electricity use is reported quarterly, without analysing efficiency and the greatest sources of energy use, making potential improvements less easy to identify.

As with site processes, there remains a strong focus on avoiding employee and environmental accidents (SDGs $3 \& 15$ in Figure 6). Almost all processes contain a risk assessment and appropriate mitigation for any human risks. Environmental risks mitigation particularly focuses on avoiding oil and hydraulic fluid contamination; for examples, "plant nappies" are used to proactively catch any leaking oil (score of 3), whilst spill kits offer a reactive way to mitigate the impacts of any spills that do occur (score of 2).

\subsection{Human Resources}

Throughout the HR life cycle, there are processes that cover the recruitment of employees, their induction, their development and training and ultimately their leaving the business. This range of roles means HR is made up of 53 different processes. Throughout all these processes and procedures, HR has some of the greatest impacts on social sustainability (Figure 7). As with HSEQ, the vast majority of processes are about ensuring legal compliance in the UK. This means there are many reporting requirements (score of 1), like gender pay and bonus gap reporting (SDG5) and maternity/paternity leave reporting (SDG 5). Hence we see interquartile ranges for gender equality (SDG 5), reduced inequality (SDG 10) and peace, justice \& strong institutions (SDG 16) that are all between no impact (score of 0 ) and routinely reported (score of 1 in Figure 7).

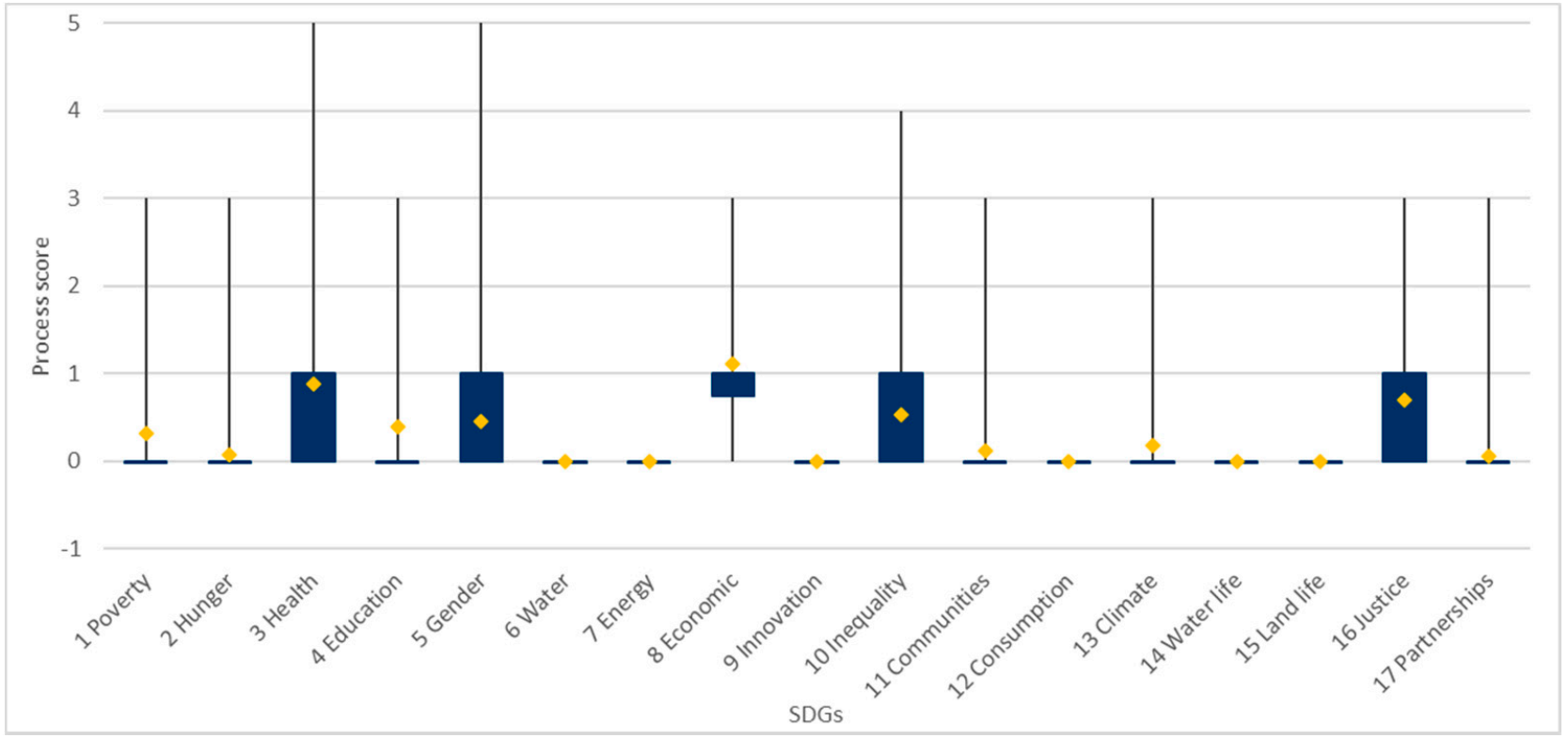

Figure 7. HR box and whisker plot.

HR policies and procedures encompass many ways to both proactively avoid negative sustainability impacts (score of 3) and deal with them when they occur (score of 2). For example, annual performance development reviews include ways to proactively identify staff professional development with training opportunities (SDG 4) and provide the potential to switch business functions (SDG 8). Likewise, anti-bullying and harassment procedures focus both on ways to prevent bullying (SDGs $5 \& 10$ ), as well as setting out the processes for when a complaint is raised. Drugs and alcohol misuse (SDG 3) and 
anti-bribery and corruption (SDG 16) procedures follow similar approaches. In fact, these SDGs are routinely impacted by HR, with over half of all HR processes impacting SDGs 3, 5,10 and 16 in some way (Figure 7).

There are also a number of processes that actively try and improve the well-being, diversity and health of employees, scoring a 4 or 5 in Figure 7. For example, the "investors in diversity" scheme, which audits and accredits how companies perform on diversity, equity and inclusion, contributes to many of these positive impacts (SDG 5 and 10). Whilst the audits are a reporting process in themselves, the investors in diversity scheme influences the sustainability of a number of processes. This includes adding key additional steps to encourage the recruitment and retention of a broader range of employees. On health and well-being (SDG 3), the highest scores come from annual health screenings; these help employees create personalised health plans, keeping employees healthy and catching any health concerns early.

Although most HR processes are focused on social sustainability, they also have some environmental impacts (Figure 8). The cycle to work scheme, which lends employees funds to buy a bike, encourages employees to be more active and cycle to work. Alongside appropriate road safety measures, this has positive impacts on air quality and congestion (SDG 11), as well as employee health (SDG 3). The company car scheme also ensures all new cars meet minimum air quality and emission standards (SDG 11 and 13). Whilst there are not yet requirements for electric or hybrid vehicles, setting minimum air quality standards when purchasing company cars is a proactive way to improve air quality around sites and offices.

\subsection{Procurement}

Procurement processes impact both the sustainability of geotechnical companies and their supply network. As you can see in Figure 8, the 15 core procurement processes cover a broad range of SDGs. However, none of these processes look to actively improve sustainability, with the best scores only reaching proactive ways to minimise harm (score of 3).

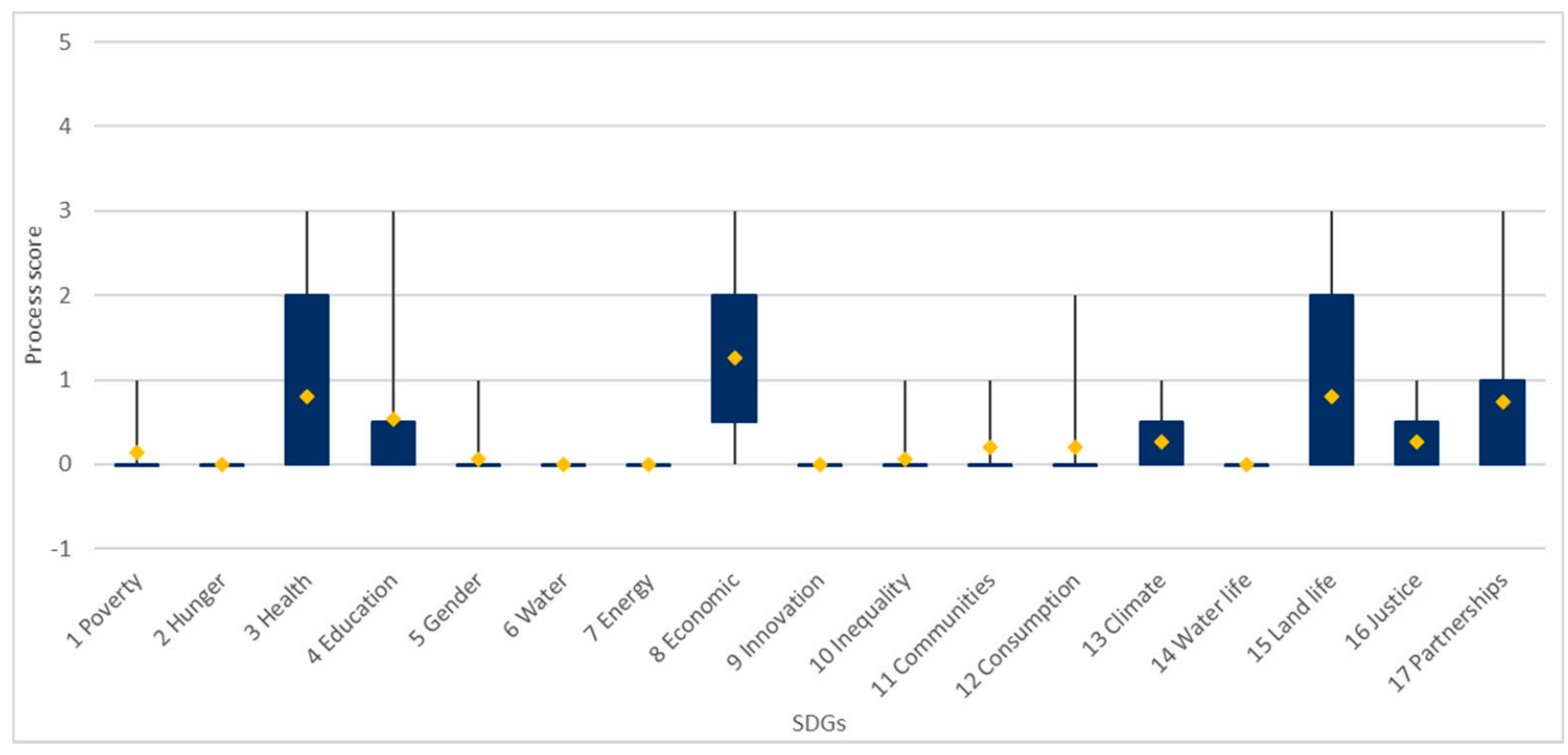

Figure 8. Procurement box and whisker plot.

Most procurement processes focus on ensuring suppliers meet minimum criteria, including basic environmental and social sustainability reporting. Whilst this covers many areas of environmental, social and economic sustainability, this means average scores rarely exceeds reporting of sustainability impacts (score of 1) (Figure 8). For example, the supplier approval questionnaire asks potential suppliers to disclose the number of environmental 
prosecutions they've received (SDG 15), as well as whether they've been prosecuted for health \& safety accidents (SDG 3).

Suppliers that are essential to Keller's operations are also required to supply evidence of ISO 9001 quality management standard (SDG 8), ISO 14001 environmental management standard (SDG 15), and ISO 45001 occupational health and safety management standard (SDG 3). Together with occasional audits, this helps to ensure suppliers have procedures in place to identify, mitigate and remediate basic quality, environmental and health and safety incidences (score of 3).

Given geotechnical companies work with a wide range of local suppliers, from concrete and aggregate suppliers to specialist cage manufacturers, each type of supplier has their own supplier approval questionnaire. Aside from ensuring proactive quality controls are in place though (SDG 8), there is little in terms of identifying innovation in the supply chain or rewarding 'more sustainable' materials. Without a way to recognise and reward the sustainable use of materials, this limits the current sustainability impact of procurement [31]. The only influence on climate (SDG 13) and responsible consumption and production (SDG 12) comes from ensuring transportation companies meet minimum emission certifications such as FORS [32]. This means that whilst scope 3 emissions can be calculated at a project level by estimating or site operation functions, procurement processes mostly do not actively highlight more sustainable materials or solutions.

\subsection{Estimating, Marketing \& Strategy}

It is worth noting that estimating, marketing \& strategy functions only have 9, albeit comprehensive, recorded processes. As a result, to calculate a more relevant average and interquartile range, the inter-related functions of estimating and marketing \& strategy have been grouped together. Despite this, the small number of processes means one process has more impact on the average and the interquartile ranges than some of the other functions. It is also worth noting that whilst this is a small number of processes, these processes have a large impact on projects undertaken on by a geotechnical company; as such, these functions are a core part of the overall business.

Unsurprisingly, estimating has many impacts on economic sustainability (SDG 8) (Figure 9). Clearly costing jobs and managing bids, so that geotechnical companies can win a project and still make a profit, is integral to the long-term economic sustainability of any geotechnical company.

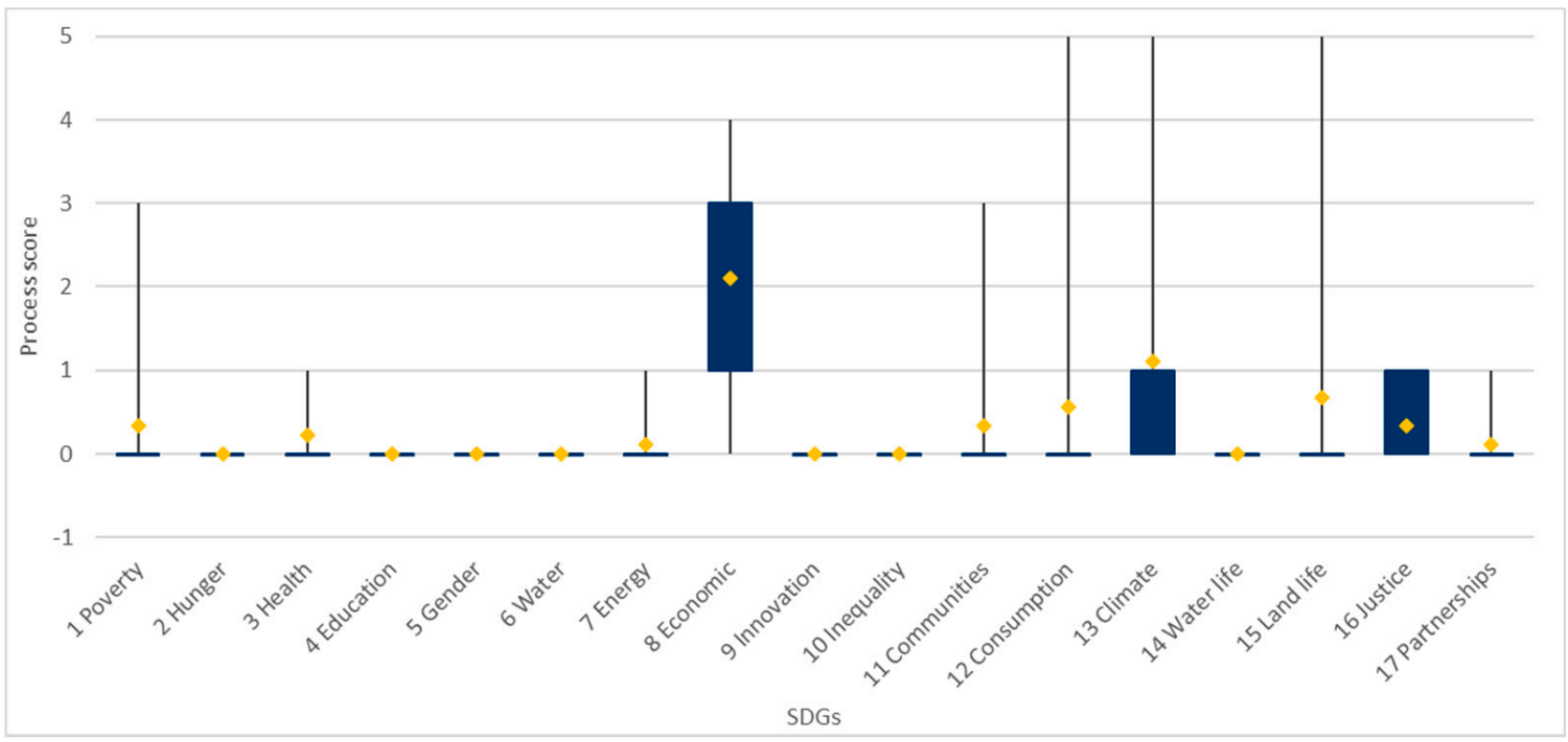

Figure 9. Estimating, marketing and strategy box and whisker plot. 
Early engagement in the beginning of geotechnical projects means that estimating can also have a positive impact on carbon emissions/resilience (SDG 13), resource use (SDG 12) and other factors in the project (Figure 9). For example, the proactive use of a sustainability brochure to help clients identify 'more sustainable' geotechnical solutions has positive impacts on multiple SDGs. Actively marketing lower embodied carbon and lower waste solutions, such as ground improvement, over traditional piling options, reduces material consumption and lowers embodied carbon (SDGs 12 \& 13) [5,6]. Importantly, offering more sustainable solutions also means a geotechnical company can gain a competitive advantage, improving the company's profit margin (SDG 8). Other processes focus on promoting ground improvement to treat and contain contaminated ground. This encourages the reuse of brownfield sites and remediating poor ground quality (SDG 15). Focus is also placed on identifying solutions to local sustainability requirements for clients, such as reducing noise for the local community (SDG 11).

\subsection{IT}

Whilst IT is the smallest function considered in this investigation, with just 4 key processes covering IT purchasing, use, support and strategy, it has an impact on a number of environmental, social and economic SDGs. The only social impacts come from the IT use restrictions, with IT able to monitor and restrict access to certain websites. Whilst it is down to HR to address anti-bullying in their own processes, this means IT is essential for reporting discrimination based on gender (SDG 5) or other minority status (SDG 10) (Figure 10).

The negative energy score in Figure 10 comes from a lack of consideration for energy efficiency when purchasing equipment. Whilst complying with legislation, such as the Waste from Electrical and Electronic Equipment (WEEE) directive [33] (SDG 16), the lack of energy efficiency considerations could affect the energy demand throughout the equipment's lifecycle (SDG 7). Although a greater energy use would increase energy costs (SDG 8), equipment purchasing controls overall help reduce IT costs. Purchasing processes ensure all computers, laptops and monitors are purchased from the same IT brand. This reduces the number of spare parts the IT function need to keep, helping to reduce waste parts (SDG 12) and minimise repair costs (SDG 8).

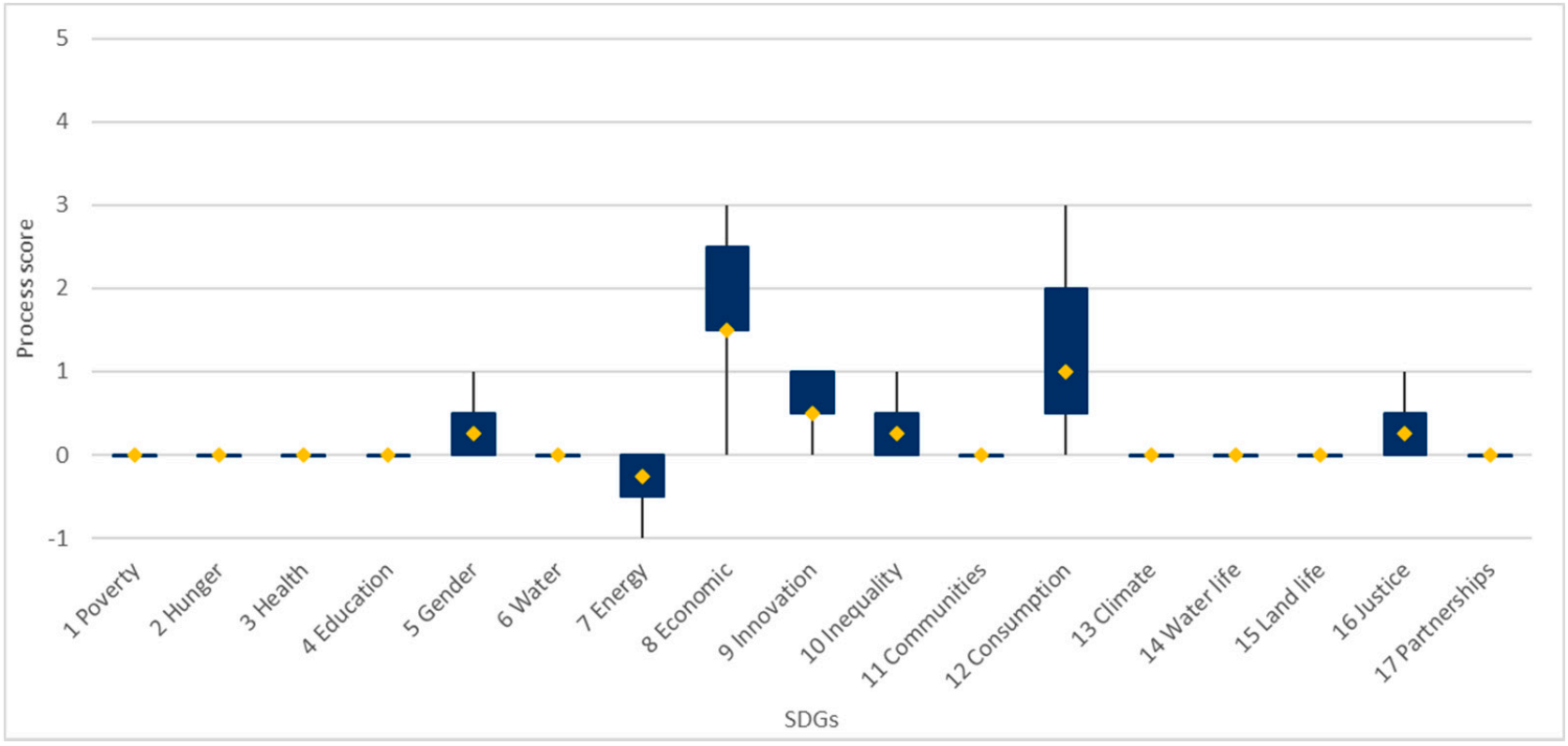

Figure 10. IT box and whisker plot. 


\subsection{Finance}

Again, the small number of processes in Finance mean the average and interquartile range are strongly influenced by one process (Figure 11); just 5 broad, key processes cover all the operations of this function. Nonetheless, the vast majority of financial processes impacts three main SDGs: no poverty (SDG 1), decent work \& economic growth (SDG 8) and partnerships for the goals (SDG 17). Through managing payments, for employees, suppliers and wider contracts, the finance function is essential for meeting basic social and economic sustainability requirements. For the long-term economic sustainability of a geotechnical company (SDG 8), economic reporting and forecasting are essential.

The one financial process to influence different SDGs is carbon reporting. This process, currently compiled by finance, requires the quarterly disclosure of Scope 1 and 2 emissions; this covers direct emissions from fuel use on site, as well as indirect emissions from electricity use [34]. In Keller, this is also third-party verified to ISO 14064. Whilst emission reporting should be encouraged, this only scores a 1 for SDGs $7 \& 13$ (Figure 11), as it only reports carbon rather than reducing emissions. Nonetheless, this is invaluable in informing and targeting other carbon reduction activities.

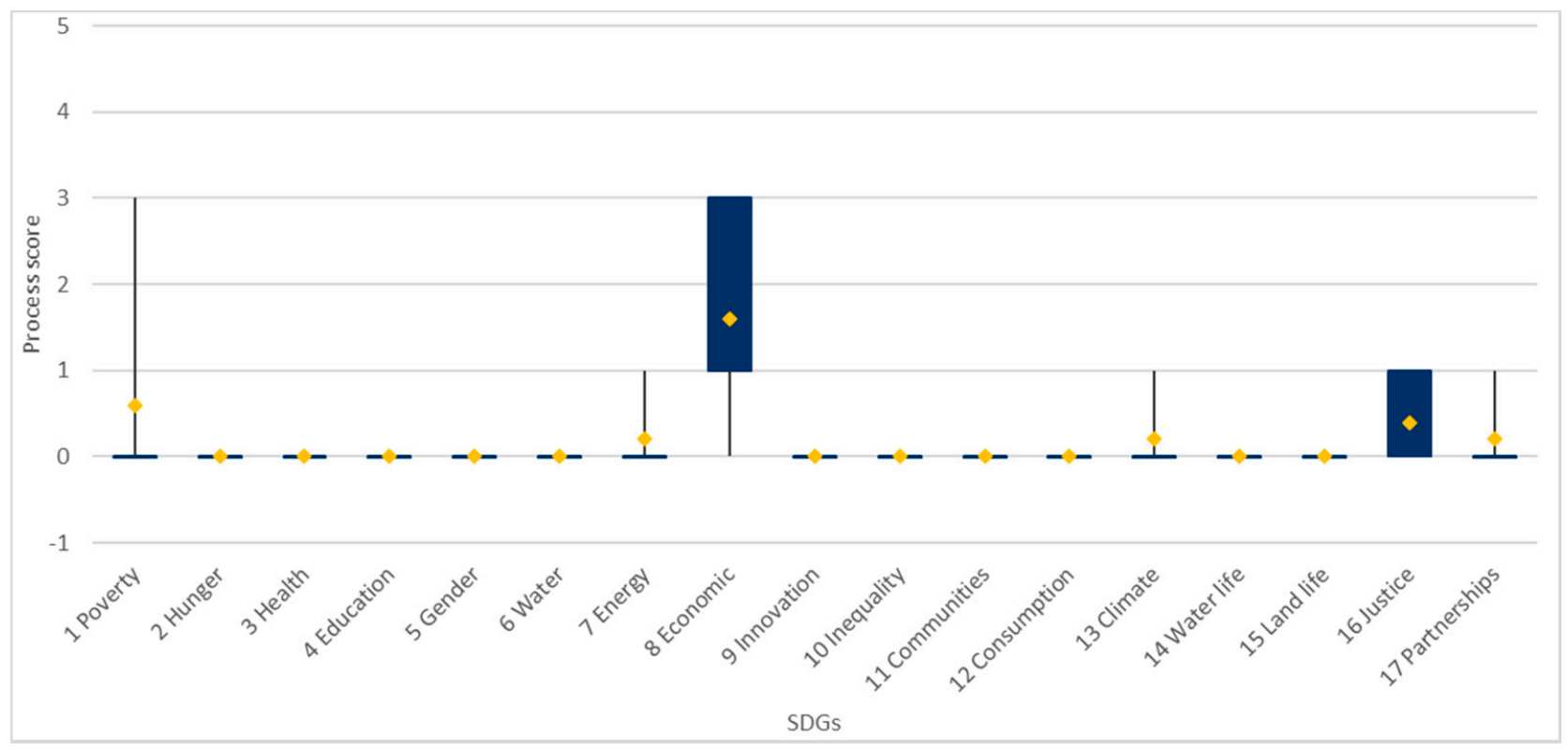

Figure 11. Finance box and whisker plot.

\section{Conclusions}

This paper explores all the processes carried out across a geotechnical company, assessing their impact against the SDGs using a pedigree matrix approach. These processes are grouped by business function, highlighting the impacts associated with each part of the business. The approach also identifies those individual processes that have the greatest impact on the overall sustainability of the company.

In terms of theoretical conclusions, this active research currently offers one of the most detailed snapshots of sustainability impacts across a whole geotechnical company. The process-led pedigree matrix approach is also novel for the sector; the successful application of an SDG-based pedigree matrix to such a range of processes means it could be a new tool for the assessment of company sustainability. However, the real value of this paper is in highlighting how this research can be applied in a real-world setting. For this, we must also document the practical conclusions of this research.

Firstly, geotechnical companies influence all 17 SDGs in some way. In relation to the aim of identifying as many sustainability impacts as possible, this is a significant 
result; when compared to previous papers [2-4,7], the approach used highlights far more sustainability impacts than previous authors have suggested. This is because previous papers have focused on project and site-based impacts, rather than taking a whole company approach. Indeed, when it comes to certain SDGs, especially inequality and gender equality (SDGs $5 \& 10$ ), this paper highlights far more impacts outside of site operations. The identification of this knowledge gap emphasises the need to look beyond project and site-based improvements when assessing the sustainability of whole companies.

Secondly, the sustainability impacts of geotechnical companies are not spread evenly across all business functions. In relation to this aim, the bottom-up assessment used in this paper successfully identifies specific processes that are responsible for certain sustainability impacts. Unlike top-down company assessments $[2,3,10,11]$, this bottom-up approach means geotechnical companies can focus their sustainability efforts on improving specific processes, based on their sustainability priorities. Previous attempts to assess the overall sustainability impacts of a company from the top down have also missed the processlevel impacts highlighted in this paper. Again, this illustrates the real value of assessing sustainability at a process level and subsequently aggregating these up into business functions.

In terms of specific impacts, it is worth highlighting the current focus throughout every function on improving good health and well-being (SDG 3) and decent work and quality (SDG 8). This understandably reflects the focus on safety and quality from clients and company leaders [8], as well as compliance with standards such as ISO 45001 and ISO 9001. Whilst individual processes did achieve positive scores for the other SDGs, most processes currently only report on these sustainability impacts. This discrepancy with SDGs 3 and 8 perhaps suggests wider sustainability impacts may not yet be core to the business of geotechnical companies. Hence, geotechnical companies might wish to reframe sustainability within a framework similar to health and safety, focusing on embedding positive sustainability impacts in every business process.

Clearly each geotechnical company is likely to have different sustainability impacts compared to those in this investigation. As such, companies should be careful not to infer their own impacts from this paper. Instead, they should consider using the approach outlined to assess their own sustainability profile. Equally, the sustainability impacts in this case study do not necessarily highlight where most improvements can be made. However, this paper offers a potential baseline for targeting improvements in the future. As well as optimising where sustainability resources are invested, this helps keep sustainability relevant to business functions and employees. By making sustainability relevant to each role, the approach facilitates a natural engagement of employees at all levels. Ensuring sustainability is relevant to individual roles is essential to overcoming many existing barriers to sustainability $[10,35]$.

The pedigree matrix approach outlined in this paper is also useful for comparisons between geotechnical companies. By comparing the sustainability impacts of the same functions and process in different companies, this approach can help identify which process is more sustainable. Future research may therefore highlight sustainability best practices for individual processes, determined by these multiple comparisons. These incremental improvements, that enable the adoption of best practice for individual processes, will be essential to drive sustainability gains in geotechnical companies. Therefore, alongside the large step changes required for meeting the SDGs, this approach is a constructive way to drive improvements across a company.

Author Contributions: Conceptualization, L.D., J.L., M.M. and J.D.W.; methodology, L.D.; validation, J.L., M.M. and J.D.W.; formal analysis, L.D.; investigation, L.D.; resources, L.D.; data curation, L.D.; writing — original draft preparation, L.D.; writing—review and editing, L.D., J.L., M.M. and J.D.W.; visualization, L.D.; supervision, J.L., M.M. and J.D.W.; project administration, L.D. All authors have read and agreed to the published version of the manuscript.

Funding: This research is part of the corresponding author's Practitioner Doctorate in Sustainability, which is fully funded by Keller Group plc. No additional research grant was used for this paper. 
Data Availability Statement: As company processes are proprietary to Keller, restrictions apply to the availability of the data. Data was obtained from Keller and is available from the authors only with the permission of Keller Group. The pedigree matrix data presented in this study is available in the Appendix A.

Conflicts of Interest: The authors declare no conflict of interest. Keller Group plc played no role in the design of the study; in the collection, analyses, or interpretation of data; in the writing of the manuscript; or in the decision to publish the results.

\section{Appendix A Pedigree Matrix}

The pedigree matrix is used to allocate each SDG score to a process. In cases where processes can fit in more than one category for a single SDG (e.g., for SDG 1 a process ensures a reactive response to employees poverty but worsens financial well-being for employees), part (a) of a description is given preference over part (b) which is given preference over part (c) and so on. Any conflicts resolved in this way are noted as comments. 


\begin{tabular}{|c|c|c|c|c|c|c|c|}
\hline SDG & $\begin{array}{c}-1 \\
\text { Negative/Unreported }\end{array}$ & $\begin{array}{c}0 \\
\text { No Impact }\end{array}$ & $\begin{array}{c}1 \\
\text { Report }\end{array}$ & $\begin{array}{c}2 \\
\text { Reactive, Minimise }\end{array}$ & $\begin{array}{c}3 \\
\text { Proactive, Minimise }\end{array}$ & $\begin{array}{c}4 \\
\text { Positive, Proactive }\end{array}$ & $\begin{array}{c}5 \\
\text { Best Practice }\end{array}$ \\
\hline $\begin{array}{c}1 \\
\text { No poverty }\end{array}$ & $\begin{array}{l}\text { (a) Increases poverty } \\
\text { or (b) decreases } \\
\text { financial well-being } \\
\text { of individuals, } \\
\text { without recording } \\
\text { these impacts }\end{array}$ & $\begin{array}{l}\text { No influence on }(\mathrm{y}) \\
\text { poverty or }(\mathrm{z}) \\
\text { financial well-being } \\
\text { individuals }\end{array}$ & $\begin{array}{l}\text { Ensures minimum } \\
\text { reporting \& policies } \\
\text { on employee wages, } \\
\text { including whether all } \\
\text { employees are on a } \\
\text { living wage (e.g., } \\
\text { monitor \& avoid } \\
\text { modern slavery) }\end{array}$ & $\begin{array}{l}\text { Investigate where (a) } \\
\text { poverty or (b) poor } \\
\text { financial well-being is } \\
\text { reported, refer it to } \\
\text { relevant bodies and act } \\
\text { to stop it being repeated }\end{array}$ & $\begin{array}{l}\text { Proactively mitigate } \\
\text { the risk of (a) poverty } \\
\text { of employees or } \\
\text { encourage } \\
\text { individuals to (c) } \\
\text { seek help with } \\
\text { poverty/financial } \\
\text { well-being }\end{array}$ & $\begin{array}{l}\text { Proactively improve } \\
\text { employee (a) pay, } \\
\text { conditions or (b) } \\
\text { financial well-being. }\end{array}$ & $\begin{array}{l}\text { Innovative best } \\
\text { practice, leading the } \\
\text { sector in supporting } \\
\text { financial well-being } \\
\text { among individuals, } \\
\text { actively preventing } \\
\text { poverty/exploitation } \\
\text { \&/or lifting out other } \\
\text { stakeholders out of } \\
\text { these situations }\end{array}$ \\
\hline $\begin{array}{c}2 \\
\text { Zero hunger }\end{array}$ & $\begin{array}{l}\text { (a) Actively increases } \\
\text { hunger of } \\
\text { individuals without } \\
\text { recording these } \\
\text { impacts }\end{array}$ & $\begin{array}{l}\text { (z) No impact on } \\
\text { hunger of } \\
\text { individuals }\end{array}$ & $\begin{array}{l}\text { (a) Ensures minimum } \\
\text { reporting of } \\
\text { employee } \\
\text { hunger / food welfare }\end{array}$ & $\begin{array}{l}\text { (a) Supports employees } \\
\text { with a food allowance } \\
\text { when working on } \\
\text { site/away from home }\end{array}$ & $\begin{array}{l}\text { (a) Identifies } \\
\text { individuals at risk of } \\
\text { going hungry } \\
\text { throughout business } \\
\text { and gives these } \\
\text { individuals required } \\
\text { support }\end{array}$ & $\begin{array}{l}\text { (a) Regular initiatives } \\
\text { to (a) tackle } \\
\text { employee hunger } \\
\text { and (b) support } \\
\text { individuals at risk of } \\
\text { hunger }\end{array}$ & $\begin{array}{l}\text { Innovative best } \\
\text { practice, leading the } \\
\text { sector with tailored } \\
\text { support for } \\
\text { individuals } \\
\text { hunger/diet }\end{array}$ \\
\hline $\begin{array}{c}3 \\
\text { Good health and } \\
\text { well-being }\end{array}$ & $\begin{array}{l}\text { Actively decreases } \\
\text { the (a) health \& }(b) \\
\text { well-being of } \\
\text { individuals without } \\
\text { recording these } \\
\text { impacts }\end{array}$ & $\begin{array}{l}\text { No influence on the } \\
\text { (y) health \& (z) } \\
\text { well-being of } \\
\text { individuals }\end{array}$ & $\begin{array}{l}\text { Ensures minimum } \\
\text { procedure to record } \\
\text { poor (a) or (b) } \\
\text { well-being health } \\
\text { (e.g., RIDOR } \\
\text { reporting) }\end{array}$ & $\begin{array}{l}\text { Reactive methods to } \\
\text { investigate (a) poor } \\
\text { health and (b) well-being } \\
\text { to prevent harm in the } \\
\text { future }\end{array}$ & $\begin{array}{l}\text { Proactive approach, } \\
\text { looking to (a) prevent } \\
\text { harm to any } \\
\text { individuals from } \\
\text { occurring initially or } \\
\text { (b) prevent poor } \\
\text { well-being }\end{array}$ & $\begin{array}{l}\text { Proactive approach, } \\
\text { seeking to actively } \\
\text { improve the (a) } \\
\text { health and (b) } \\
\text { well-being of } \\
\text { individuals }\end{array}$ & $\begin{array}{l}\text { (a) Innovative best } \\
\text { practice, leading the } \\
\text { sector in proactively } \\
\text { improving the health } \\
\text { of all individuals }\end{array}$ \\
\hline
\end{tabular}




\begin{tabular}{|c|c|c|c|c|c|c|c|}
\hline SDG & $\begin{array}{c}-1 \\
\text { Negative/Unreported }\end{array}$ & $\begin{array}{c}0 \\
\text { No Impact }\end{array}$ & $\begin{array}{c}1 \\
\text { Report }\end{array}$ & $\begin{array}{c}2 \\
\text { Reactive, Minimise }\end{array}$ & $\begin{array}{c}3 \\
\text { Proactive, Minimise }\end{array}$ & $\begin{array}{c}4 \\
\text { Positive, Proactive }\end{array}$ & $\begin{array}{c}5 \\
\text { Best Practice }\end{array}$ \\
\hline $\begin{array}{c}4 \\
\text { Quality } \\
\text { education }\end{array}$ & $\begin{array}{l}\text { Actively decreases } \\
\text { the opportunities for } \\
\text { education of (a) } \\
\text { employees, (b) } \\
\text { apprentices or (c) } \\
\text { graduates without } \\
\text { recording these } \\
\text { impacts. }\end{array}$ & $\begin{array}{l}\text { No influence on the } \\
\text { education of }(\mathrm{x}) \\
\text { employees, }(\mathrm{y}) \\
\text { apprentices or }(\mathrm{z}) \\
\text { graduates }\end{array}$ & $\begin{array}{c}\text { Ensures (a) } \\
\text { employees are } \\
\text { sufficiently educated } \\
\text { to complete their job. } \\
\text { Report on (b) } \\
\text { apprentices or (c) } \\
\text { graduates where } \\
\text { needed }\end{array}$ & $\begin{array}{l}\text { Reactive methods to } \\
\text { support (a) employees } \\
\text { that request } \\
\text { education/CPD when } \\
\text { requested. Support (b) } \\
\text { apprentices/(c) } \\
\text { graduates where } \\
\text { required by additional } \\
\text { standards }\end{array}$ & $\begin{array}{l}\text { Helps identify } \\
\text { improvements for } \\
\text { education of (a) } \\
\text { employees, (b) } \\
\text { apprentices \& (c) } \\
\text { graduates and } \\
\text { encourages } \\
\text { individuals to take } \\
\text { up these } \\
\text { opportunities }\end{array}$ & $\begin{array}{l}\text { Actively drives (a) } \\
\text { employees, (b) } \\
\text { apprentices \& (c) } \\
\text { graduates to } \\
\text { continue educa- } \\
\text { tion/professional } \\
\text { development. } \\
\text { Approach tailored to } \\
\text { each individual. }\end{array}$ & $\begin{array}{c}\text { Consistent, } \\
\text { innovative best } \\
\text { practice, leading the } \\
\text { sector in identifying } \\
\text { \& developing talent } \\
\text { through education of } \\
\text { all (a) employees, (b) } \\
\text { apprentices \& (c) } \\
\text { graduates }\end{array}$ \\
\hline $\begin{array}{c}5 \\
\text { Gender equality }\end{array}$ & $\begin{array}{l}\text { Reduces (a) gender } \\
\text { equality or (b) } \\
\text { increases sexual } \\
\text { discrimination } \\
\text { without recording } \\
\text { these impacts }\end{array}$ & $\begin{array}{l}\text { (z) No influence on } \\
\text { gender equality }\end{array}$ & $\begin{array}{l}\text { Ensures (a) report on } \\
\text { gender equality or (b) } \\
\text { have policies on } \\
\text { sexual discrimination } \\
\text { (e.g., gender pay gap } \\
\text { reporting) }\end{array}$ & $\begin{array}{l}\text { (a) Reactive methods to } \\
\text { investigate gender } \\
\text { equality issues beyond } \\
\text { legal requirements and } \\
\text { (b) ensure lessons are } \\
\text { learnt to prevent } \\
\text { recurrences future } \\
\text { occurrences }\end{array}$ & $\begin{array}{l}\text { (a) Proactively assess } \\
\text { gender equality, } \\
\text { identify issues and } \\
\text { (b) methods to } \\
\text { minimise the } \\
\text { possibility of sexual } \\
\text { discrimination and } \\
\text { inequality }\end{array}$ & $\begin{array}{l}\text { Proactive methods to } \\
\text { (b) improve gender } \\
\text { diversity and (a) } \\
\text { correct gender } \\
\text { inequality }\end{array}$ & $\begin{array}{l}\text { Innovative best } \\
\text { practice, leading the } \\
\text { sector in (a) actively } \\
\text { preventing any } \\
\text { gender pay or (b) } \\
\text { skills gap \& (c) } \\
\text { ensuring gender } \\
\text { representation across } \\
\text { the business }\end{array}$ \\
\hline $\begin{array}{c}6 \\
\begin{array}{c}\text { Clean water \& } \\
\text { sanitation }\end{array}\end{array}$ & $\begin{array}{l}\text { Actively increases (a) } \\
\text { water use or (b) } \\
\text { water pollution } \\
\text { without recording } \\
\text { these impacts }\end{array}$ & $\begin{array}{c}\text { No impact or } \\
\text { influence on }(\mathrm{y}) \\
\text { water usage or }(\mathrm{z}) \\
\text { pollution }\end{array}$ & $\begin{array}{l}\text { Ensures minimum } \\
\text { reporting on }(\mathrm{a}) \\
\text { water usage and (b) } \\
\text { pollution }\end{array}$ & $\begin{array}{l}\text { Reactive methods to (b) } \\
\text { investigate water } \\
\text { wastage or (c) pollution } \\
\text { and (a) ensure lessons } \\
\text { are learnt for the future }\end{array}$ & $\begin{array}{l}\text { (a) Proactively assess } \\
\text { water use and (b) } \\
\text { identify large sources } \\
\text { of water wastage or } \\
\text { (c) pollution to } \\
\text { reduce/improve }\end{array}$ & $\begin{array}{c}\text { Proactively improves } \\
\text { water (c) quality and } \\
\text { (b) availability, (a) } \\
\text { prioritising water } \\
\text { minimisation in } \\
\text { decision- } \\
\text { making/methods }\end{array}$ & $\begin{array}{l}\text { Innovative best } \\
\text { practice, leading the } \\
\text { sector in improving } \\
\text { (c) water quality and } \\
\text { (b) availability, } \\
\text { prioritising (a) water } \\
\text { minimisation } \\
\text { throughout the } \\
\text { relevant life cycles }\end{array}$ \\
\hline
\end{tabular}




\begin{tabular}{|c|c|c|c|c|c|c|c|}
\hline SDG & $\begin{array}{c}-1 \\
\text { Negative/Unreported }\end{array}$ & $\begin{array}{c}0 \\
\text { No Impact }\end{array}$ & $\begin{array}{c}1 \\
\text { Report }\end{array}$ & $\begin{array}{c}2 \\
\text { Reactive, Minimise }\end{array}$ & $\begin{array}{c}3 \\
\text { Proactive, Minimise }\end{array}$ & $\begin{array}{c}4 \\
\text { Positive, Proactive }\end{array}$ & $\begin{array}{c}5 \\
\text { Best Practice }\end{array}$ \\
\hline $\begin{array}{c}7 \\
\text { Affordable \& } \\
\text { clean energy }\end{array}$ & $\begin{array}{l}\text { Actively(a) decreases } \\
\text { efficiency or (b) } \\
\text { increases use of } \\
\text { non-renewable } \\
\text { energy without } \\
\text { recording these } \\
\text { impacts }\end{array}$ & $\begin{array}{l}\text { No material impact } \\
\text { on (z) energy use or } \\
\text { (y) energy efficiency }\end{array}$ & $\begin{array}{l}\text { Ensures minimum } \\
\text { reporting on(a) } \\
\text { renewable energy } \\
\text { use, (b) energy use, } \\
\text { or (c) energy } \\
\text { efficiency (e.g., ESOS } \\
\text { audits) }\end{array}$ & $\begin{array}{c}\text { Assess and tackle largest } \\
\text { areas of (a) } \\
\text { non-renewable use } \\
\text { picked up in ESOS or } \\
\text { other audits/legislation, } \\
\text { (b) inefficiency or (c) } \\
\text { energy use. (d) Can use } \\
\text { cleaner/lower carbon } \\
\text { fuels when requested }\end{array}$ & $\begin{array}{c}\text { Proactively \& } \\
\text { regularly assess } \\
\text { energy use, looking } \\
\text { to (a) reduce use of } \\
\text { non-renewable fuels, } \\
\text { or (b) improve } \\
\text { efficiency of existing } \\
\text { equipment. (c) Uses } \\
\text { cleaner/lower C fuel } \\
\text { as standard }\end{array}$ & $\begin{array}{l}\text { (a) Drive the } \\
\text { adoption of } \\
\text { renewable energy } \\
\text { sources; (b) increase } \\
\text { uptake of highly } \\
\text { energy efficient } \\
\text { processes; (c) looks to } \\
\text { minimise all energy } \\
\text { use; or (d) runs on } \\
\text { normal mains power } \\
\text { electricity, or low } \\
\text { emission power, as } \\
\text { standard. (e) Drives } \\
\text { the adoption of } \\
\text { engineering or } \\
\text { behavioural } \\
\text { improvements for } \\
\text { this SDG }\end{array}$ & $\begin{array}{l}\text { Innovative best } \\
\text { practice, leading the } \\
\text { sector in using (a) } \\
\text { exclusively } \\
\text { renewable energy } \\
\text { and minimising (b) } \\
\text { energy use } \\
\text { throughout relevant } \\
\text { life cycles }\end{array}$ \\
\hline $\begin{array}{c}8 \\
\text { Decent work \& } \\
\text { economic growth }\end{array}$ & $\begin{array}{l}\text { Actively decreases (a) } \\
\text { business growth, (b) } \\
\text { productivity or (c) } \\
\text { product quality } \\
\text { without recording } \\
\text { these impacts }\end{array}$ & $\begin{array}{l}\text { No material impact } \\
\text { on }(\mathrm{x}) \text { business } \\
\text { growth, (y) } \\
\text { productivity or (z) } \\
\text { product quality }\end{array}$ & $\begin{array}{c}\text { Ensures reporting on } \\
\text { (a) economic growth, } \\
\text { (b) productivity or (c) } \\
\text { quality }\end{array}$ & $\begin{array}{l}\text { Reactive methods to (a) } \\
\text { tackle areas of poor } \\
\text { economic growth, (b) } \\
\text { productivity or (c) } \\
\text { quality when they are } \\
\text { reported }\end{array}$ & $\begin{array}{l}\text { Proactive methods to } \\
\text { assess \& anticipate } \\
\text { risks to (a) economic } \\
\text { growth (b) } \\
\text { productivity or (c) } \\
\text { quality and mitigate } \\
\text { them before they } \\
\text { occur. }\end{array}$ & $\begin{array}{c}\text { (a) Relatively } \\
\text { decouples } \\
\text { environmental \& } \\
\text { social impacts of } \\
\text { operations from } \\
\text { profit. (b) Long-term } \\
\text { strategy for } \\
\text { sustainable, strong } \\
\text { growth. (c) Ensures } \\
\text { consistent product } \\
\text { quality beyond that } \\
\text { required by } \\
\text { minimum standards }\end{array}$ & $\begin{array}{c}\text { Innovative best } \\
\text { practice, leading the } \\
\text { sector in(a) } \\
\text { decoupling } \\
\text { sustainability } \\
\text { impacts from profit, } \\
\text { (b) driving long-term } \\
\text { sustainable growth } \\
\text { and (c) market } \\
\text { leading quality in all } \\
\text { products }\end{array}$ \\
\hline
\end{tabular}




\begin{tabular}{|c|c|c|c|c|c|c|c|}
\hline SDG & $\begin{array}{c}-1 \\
\text { Negative/Unreported }\end{array}$ & $\begin{array}{c}0 \\
\text { No Impact }\end{array}$ & $\begin{array}{c}1 \\
\text { Report }\end{array}$ & $\begin{array}{c}2 \\
\text { Reactive, Minimise }\end{array}$ & $\begin{array}{c}3 \\
\text { Proactive, Minimise }\end{array}$ & $\begin{array}{c}4 \\
\text { Positive, Proactive }\end{array}$ & $\begin{array}{c}5 \\
\text { Best Practice }\end{array}$ \\
\hline $\begin{array}{c}9 \\
\text { Industry, } \\
\text { infrastructure \& } \\
\text { innovation }\end{array}$ & $\begin{array}{l}\text { (a) Actively decreases } \\
\text { the sustainability of } \\
\text { infrastructure; (c) } \\
\text { actively discourages } \\
\text { innovation; (b) } \\
\text { actively decreases the } \\
\text { sustainability impact } \\
\text { of existing processes, } \\
\text { all without recording } \\
\text { these impacts }\end{array}$ & $\begin{array}{l}\text { No impact on }(\mathrm{y}) \\
\text { industry or }(\mathrm{z}) \\
\text { infrastructure } \\
\text { sustainability. No } \\
\text { impact on }(\mathrm{x}) \\
\text { innovation. }\end{array}$ & $\begin{array}{l}\text { Ensure minimum } \\
\text { reporting on ongoing } \\
\text { machinery, industry } \\
\text { and (a) innovation }\end{array}$ & $\begin{array}{l}\text { (a) React to client } \\
\text { demand or competitor } \\
\text { innovation, innovating } \\
\text { where necessary to } \\
\text { minimise impact on } \\
\text { business }\end{array}$ & $\begin{array}{l}\text { (a) Identify existing } \\
\text { sustainability } \\
\text { demand and } \\
\text { innovate to offer } \\
\text { more sustainable } \\
\text { services to clients }\end{array}$ & $\begin{array}{l}\text { (b) Specific R\&D } \\
\text { projects to create } \\
\text { more sustainable pro- } \\
\text { cesses/improvements } \\
\text { for use in all projects. } \\
\text { (a) Part of a } \\
\text { long-term strategy to } \\
\text { develop } \\
\text { sustainability in the } \\
\text { sector }\end{array}$ & $\begin{array}{l}\text { (a) Implementing } \\
\text { market leading } \\
\text { sustainability } \\
\text { innovation, (b) with } \\
\text { sustainability } \\
\text { improvements } \\
\text { embedded in } \\
\text { processes as standard } \\
\text { and (c) a long-term } \\
\text { strategy of } \\
\text { sustainability } \\
\text { continuous } \\
\text { improvement }\end{array}$ \\
\hline $\begin{array}{l}10 \\
\text { Reduced } \\
\text { inequality }\end{array}$ & $\begin{array}{l}\text { Actively increases (b) } \\
\text { inequality or (a) } \\
\text { discrimination } \\
\text { among individuals } \\
\text { without recording } \\
\text { these impacts }\end{array}$ & $\begin{array}{l}\text { No impact on }(y) \\
\text { inequality or }(\mathrm{z}) \\
\text { discrimination }\end{array}$ & $\begin{array}{l}\text { Ensures report or } \\
\text { policies on (a) } \\
\text { discrimination and } \\
\text { (b) inequality (e.g., } \\
\text { bullying \& } \\
\text { harassment policy) }\end{array}$ & $\begin{array}{l}\text { Reactive methods to } \\
\text { investigate (a) } \\
\text { discrimination and (b) } \\
\text { inequality beyond legal } \\
\text { requirements when } \\
\text { raised, ensuring lessons } \\
\text { are learnt to prevent } \\
\text { future occurrences }\end{array}$ & $\begin{array}{l}\text { Proactive assess and } \\
\text { tackle (b) inequality } \\
\text { or (a) discrimination } \\
\text { where it is occurring. } \\
\text { Encourage } \\
\text { individuals to raise } \\
\text { issues of } \\
\text { discrimination \& } \\
\text { inequality }\end{array}$ & $\begin{array}{l}\text { Proactive methods to } \\
\text { identify areas where } \\
\text { (a) discrimination \& } \\
\text { (b) inequality may } \\
\text { occur in the future \& } \\
\text { prevent them before } \\
\text { they ensue }\end{array}$ & $\begin{array}{l}\text { Innovative best } \\
\text { practice, leading the } \\
\text { sector by actively } \\
\text { developing a more } \\
\text { (b) equal \& (a) } \\
\text { inclusive working } \\
\text { environment for } \\
\text { individuals }\end{array}$ \\
\hline
\end{tabular}




\begin{tabular}{|c|c|c|c|c|c|c|c|}
\hline SDG & $\begin{array}{c}-1 \\
\text { Negative/Unreported }\end{array}$ & $\begin{array}{c}0 \\
\text { No Impact }\end{array}$ & $\begin{array}{c}1 \\
\text { Report }\end{array}$ & $\begin{array}{c}2 \\
\text { Reactive, Minimise }\end{array}$ & $\begin{array}{c}3 \\
\text { Proactive, Minimise }\end{array}$ & $\begin{array}{c}4 \\
\text { Positive, Proactive }\end{array}$ & $\begin{array}{c}5 \\
\text { Best Practice }\end{array}$ \\
\hline $\begin{array}{c}11 \\
\text { Sustainable cities } \\
\& \text { communities }\end{array}$ & $\begin{array}{l}\text { (a) Actively increases } \\
\text { particulate emissions } \\
\text { in cities, (b) decreases } \\
\text { city climate resilience } \\
\text { or (c) Negatively } \\
\text { impacts local } \\
\text { community, all } \\
\text { without recording } \\
\text { these impacts }\end{array}$ & $\begin{array}{l}\text { (x) Has no impact on } \\
\text { particulate emissions } \\
\text { in cities, (y) city } \\
\text { climate resilience or } \\
\text { (z) on the local } \\
\text { community }\end{array}$ & $\begin{array}{l}\text { Ensures minimal } \\
\text { reporting of (a) } \\
\text { particulate emissions, } \\
\text { (b) project climate } \\
\text { resilience (e.g., } \\
\text { NRMM directive) or } \\
\text { (c) impact of works } \\
\text { on the local } \\
\text { community }\end{array}$ & $\begin{array}{l}\text { (a) Reduce particulate } \\
\text { emissions \&/or (b) } \\
\text { decrease impact on } \\
\text { climate resilience \&/or } \\
\text { (c) reduce impact on } \\
\text { local community where } \\
\text { complaints or requested } \\
\text { by clients }\end{array}$ & $\begin{array}{l}\text { Proactively assess } \\
\text { and minimise } \\
\text { practices that (b) } \\
\text { reduce climate } \\
\text { resilience \&/or (a) } \\
\text { offer reduced } \\
\text { particulate emissions } \\
\text { to all clients \&/or (c) } \\
\text { proactively reduce } \\
\text { impact on local } \\
\text { community }\end{array}$ & $\begin{array}{l}\text { (b) Increase climate } \\
\text { resilience and } \\
\text { minimise all (a) } \\
\text { particulate emissions } \\
\text { across all processes \& } \\
\text { projects as standard } \\
\& / \text { or (c) have a } \\
\text { positive impact on } \\
\text { the local community }\end{array}$ & $\begin{array}{l}\text { Innovative best } \\
\text { practice, (a) } \\
\text { producing ultra-low } \\
\text { to no particulate } \\
\text { emissions, including } \\
\text { the supply chain. (b) } \\
\text { More climate resilient } \\
\text { infrastructure is } \\
\text { made as standard. (c) } \\
\text { Each local } \\
\text { community actively } \\
\text { improved based on } \\
\text { local requirements }\end{array}$ \\
\hline $\begin{array}{c}12 \\
\text { Responsible } \\
\text { consumption \& } \\
\text { production }\end{array}$ & $\begin{array}{l}\text { Actively increases (a) } \\
\text { resource } \\
\text { consumption, (b) } \\
\text { waste production or } \\
\text { (c) waste to landfill } \\
\text { without recording } \\
\text { these impacts }\end{array}$ & $\begin{array}{l}\text { Has no impact on }(\mathrm{x}) \\
\text { resource } \\
\text { consumption, }(\mathrm{y}) \\
\text { waste production \& } \\
\text { (z) waste to landfill }\end{array}$ & $\begin{array}{l}\text { Ensures minimum } \\
\text { recording of (a) } \\
\text { resource use, (b) } \\
\text { waste production \& } \\
\text { waste disposal }\end{array}$ & $\begin{array}{c}\text { (a) Monitor main } \\
\text { resource \&/or waste } \\
\text { streams. Reduce (b) } \\
\text { resource use or (b) waste } \\
\text { when requested by } \\
\text { clients for specific } \\
\text { projects }\end{array}$ & $\begin{array}{l}\text { (a) Assess all existing } \\
\text { resource use and } \\
\text { waste. Proactively } \\
\text { offer to decrease (b) } \\
\text { raw material use, (c) } \\
\text { decrease waste \&/or } \\
\text { (d) increase recycling } \\
\text { to all clients }\end{array}$ & $\begin{array}{l}\text { (a) Assess and set } \\
\text { targets for resource } \\
\text { use and waste, } \\
\text { including impacts on } \\
\text { supply network. Use } \\
\text { solutions/processes } \\
\text { that specifically use } \\
\text { (b) less raw materials } \\
\text { or (c) produce less } \\
\text { waste as standard }\end{array}$ & $\begin{array}{c}\text { Innovative, market } \\
\text { leading best practice, } \\
\text { using (b) minimal } \\
\text { new materials, (a) } \\
\text { low carbon materials, } \\
\text { (c) creating minimal } \\
\text { waste or (d) stopping } \\
\text { waste to landfill. } \\
\text { Apply these practices } \\
\text { to all processes as } \\
\text { standard }\end{array}$ \\
\hline
\end{tabular}




\begin{tabular}{|c|c|c|c|c|c|c|c|}
\hline SDG & $\begin{array}{c}-1 \\
\text { Negative/Unreported }\end{array}$ & $\begin{array}{c}0 \\
\text { No Impact }\end{array}$ & $\begin{array}{c}1 \\
\text { Report }\end{array}$ & $\begin{array}{c}2 \\
\text { Reactive, Minimise }\end{array}$ & $\begin{array}{c}3 \\
\text { Proactive, Minimise }\end{array}$ & $\begin{array}{c}4 \\
\text { Positive, Proactive }\end{array}$ & $\begin{array}{c}5 \\
\text { Best Practice }\end{array}$ \\
\hline $\begin{array}{c}13 \\
\text { Climate action }\end{array}$ & $\begin{array}{l}\text { (a) Actively increases } \\
\text { carbon intensity of } \\
\text { operations or (b) } \\
\text { decreases the climate } \\
\text { resilience of solutions } \\
\text { (projects/processes) } \\
\text { without recording } \\
\text { these impacts }\end{array}$ & $\begin{array}{l}\text { Has no impact on the } \\
\text { (y) carbon intensity } \\
\text { of operations or }(\mathrm{z}) \\
\text { climate resilience of } \\
\text { solutions }\end{array}$ & $\begin{array}{l}\text { Ensures minimal (a) } \\
\text { carbon reporting } \\
\text { (e.g., C scope } 1 \& 2 \\
\text { reporting) }\end{array}$ & $\begin{array}{c}\text { (a) Monitor \& verify } \\
\text { carbon emissions beyond } \\
\text { legal requirements. (b) } \\
\text { Determine climate risk } \\
\text { exposure and (c) largest } \\
\text { source of emissions } \\
\text { where requested by } \\
\text { clients }\end{array}$ & $\begin{array}{l}\text { Proactively offer all } \\
\text { clients (a) lower } \\
\text { carbon intensity } \\
\text { \&/or (b) increased } \\
\text { climate resilience. } \\
\text { Monitor drivers for } \\
\text { tackling emissions in } \\
\text { the future }\end{array}$ & $\begin{array}{l}\text { Redesign/use } \\
\text { alternative processes } \\
\text { to (a) reduce carbon } \\
\text { emissions. (b) } \\
\text { Ensures all a more } \\
\text { resilient solution(s) } \\
\text { for all projects as } \\
\text { standard }\end{array}$ & $\begin{array}{l}\text { Innovative, market } \\
\text { leading best practice, } \\
\text { with (b) climate } \\
\text { resilience for } 1 \text { in } \\
>100 \text { year weather } \\
\text { and (b) carbon } \\
\text { negative or carbon } \\
\text { neutral practices } \\
\text { used as standard }\end{array}$ \\
\hline $\begin{array}{c}14 \\
\text { Life below water }\end{array}$ & $\begin{array}{l}\text { (a) Actively causes or } \\
\text { promotes water } \\
\text { pollution without } \\
\text { recording these } \\
\text { impacts }\end{array}$ & $\begin{array}{l}\text { Has no impact on }(\mathrm{z}) \\
\text { water pollution }\end{array}$ & $\begin{array}{l}\text { (a) Ensures recording } \\
\& \text { reporting of water } \\
\text { pollution incidences }\end{array}$ & $\begin{array}{l}\text { (a) Reactively identify } \\
\text { common incidences \& } \\
\text { Ensures all lessons are } \\
\text { learnt to prevent future } \\
\text { occurrences }\end{array}$ & $\begin{array}{l}\text { (b) Increase } \\
\text { employee awareness } \\
\text { of marine issues; (a) } \\
\text { proactively identify } \\
\text { potential risks and } \\
\text { mitigate them before } \\
\text { they occur. }\end{array}$ & $\begin{array}{l}\text { (b) Safeguards } \\
\text { marine environment } \\
\text { and (a) creates net } \\
\text { improvements in } \\
\text { marine environ- } \\
\text { ment/biodiversity }\end{array}$ & $\begin{array}{l}\text { Innovative, best } \\
\text { practice with (a) a } \\
\text { solely positive } \\
\text { impact on the marine } \\
\text { environment and } \\
\text { wildlife }\end{array}$ \\
\hline $\begin{array}{l}15 \\
\text { Life on land }\end{array}$ & $\begin{array}{l}\text { (a) Actively causes or } \\
\text { promotes } \\
\text { environmental } \\
\text { pollution without } \\
\text { recording these } \\
\text { impacts }\end{array}$ & $\begin{array}{c}\text { Has no impact on }(z) \\
\text { environmental } \\
\text { pollution }\end{array}$ & $\begin{array}{l}\text { (a) Ensures recording } \\
\& \text { reporting of } \\
\text { environmental } \\
\text { incidences }\end{array}$ & $\begin{array}{l}\text { (a) Reactively identify } \\
\text { common incidences \& } \\
\text { ensures all lessons are } \\
\text { learnt to prevent future } \\
\text { occurrences }\end{array}$ & $\begin{array}{c}\text { (b) Increase } \\
\text { employee awareness } \\
\text { of environmental } \\
\text { issues; (a) proactively } \\
\text { identify potential } \\
\text { risks and mitigate } \\
\text { them before they } \\
\text { occur. }\end{array}$ & $\begin{array}{l}\text { (b) Safeguards } \\
\text { environment and (a) } \\
\text { creates net } \\
\text { improvements for the } \\
\text { environ- } \\
\text { ment/biodiversity }\end{array}$ & $\begin{array}{c}\text { Innovative, best } \\
\text { practice with (a) a } \\
\text { solely positive } \\
\text { impact on } \\
\text { environment and } \\
\text { wildlife in the } \\
\text { company and supply } \\
\text { network }\end{array}$ \\
\hline
\end{tabular}




\begin{tabular}{|c|c|c|c|c|c|c|c|}
\hline SDG & $\begin{array}{c}-1 \\
\text { Negative/Unreported }\end{array}$ & $\begin{array}{c}0 \\
\text { No Impact }\end{array}$ & $\begin{array}{c}1 \\
\text { Report }\end{array}$ & $\begin{array}{c}2 \\
\text { Reactive, Minimise }\end{array}$ & $\begin{array}{c}3 \\
\text { Proactive, Minimise }\end{array}$ & $\begin{array}{c}4 \\
\text { Positive, Proactive }\end{array}$ & $\begin{array}{c}5 \\
\text { Best Practice }\end{array}$ \\
\hline $\begin{array}{c}16 \\
\text { Peace, justice \& } \\
\text { strong } \\
\text { institutions }\end{array}$ & $\begin{array}{l}\text { Undermines or } \\
\text { weakens }(\mathrm{a}) \\
\text { government/(b) } \\
\text { institution policy \& } \\
\text { frameworks without } \\
\text { recording these } \\
\text { impacts }\end{array}$ & $\begin{array}{l}\text { Has no impact on }(\mathrm{y}) \\
\text { government } /(\mathrm{z}) \\
\text { institution policies \& } \\
\text { frameworks }\end{array}$ & $\begin{array}{l}\text { Ensures compliance } \\
\text { with local existing (a) } \\
\text { government } \\
\text { initiatives, (b) } \\
\text { policies and } \\
\text { legislation }\end{array}$ & $\begin{array}{l}\text { Use announced (a) } \\
\text { legislation and (b) } \\
\text { government priorities to } \\
\text { shape company } \\
\text { sustainability initiatives }\end{array}$ & $\begin{array}{l}\text { Continually monitor } \\
\text { upcoming (a) } \\
\text { legislation \& (b) } \\
\text { policies to anticipate } \\
\& \text { shape company } \\
\text { sustainability } \\
\text { priorities }\end{array}$ & $\begin{array}{c}\text { Proactively mobilises } \\
\text { individual } \\
\text { individuals to } \\
\text { contribute to } \\
\text { upcoming (a) } \\
\text { legislation/(b) } \\
\text { policies to encourage } \\
\text { and strengthen } \\
\text { sustainable } \\
\text { development in the } \\
\text { sector. }\end{array}$ & $\begin{array}{l}\text { Take a leading role in } \\
\text { (a) shaping \& (b) } \\
\text { support } \\
\text { sustainability policy } \\
\text { \& sector-wide } \\
\text { development, with } \\
\text { company resources } \\
\text { put into these } \\
\text { improvements }\end{array}$ \\
\hline $\begin{array}{l}17 \\
\text { Partnerships for } \\
\text { the goals }\end{array}$ & $\begin{array}{l}\text { Actively isolates } \\
\text { company from } \\
\text { collaborations with } \\
\text { (b) trade and other } \\
\text { stakeholders without } \\
\text { recording these } \\
\text { impacts }\end{array}$ & $\begin{array}{l}\text { Has no impact on } \\
\text { formation of } \\
\text { collaborations with } \\
\text { (z) trade and (y) } \\
\text { other stakeholders }\end{array}$ & $\begin{array}{c}\text { (b) Minimum } \\
\text { collaboration, only } \\
\text { when necessitated. } \\
\text { (a) Passively comply } \\
\text { with trade } \\
\text { associations where } \\
\text { overwhelming client } \\
\text { impetus }\end{array}$ & $\begin{array}{l}\text { (b) Partake in trade } \\
\text { associations and other } \\
\text { collaborations. (a) } \\
\text { Monitor sustainability } \\
\text { opportunities that arise } \\
\text { \& implement when } \\
\text { demanded }\end{array}$ & $\begin{array}{l}\text { Contribute towards } \\
\text { (a) collaborations and } \\
\text { work with (b) trade } \\
\text { associations where } \\
\text { sustainability } \\
\text { opportunities are } \\
\text { presented. }\end{array}$ & $\begin{array}{l}\text { (a) Actively lead } \\
\text { collaboration } \\
\text { specifically to } \\
\text { improve sustainable } \\
\text { development in the } \\
\text { sector. (b) Work } \\
\text { towards actionable } \\
\text { sustainability aims or } \\
\text { processes }\end{array}$ & $\begin{array}{l}\text { Take a leading role in } \\
\text { (d) forming, (c) } \\
\text { shaping \& (b) } \\
\text { supporting sector } \\
\text { trade organisations } \\
\text { and collaborations } \\
\text { for sustainability. (a) } \\
\text { Provide company } \\
\text { resources and share } \\
\text { sustainability best } \\
\text { practices }\end{array}$ \\
\hline
\end{tabular}




\section{References}

1. Keller Group plc. Keller Group plc Annual Report and Accounts 2020. 2021. Available online: https://investors.keller.com/ \{\}/ media/Files/K/Keller-IR/downloads/09032021/keller-ar20.pdf (accessed on 8 October 2021).

2. The Federation of Piling Specialists. The Federation of Piling Specialists Sustainability Charter; The Federation of Piling Specialists: Faversham, UK, 2007.

3. Basu, D.; Misra, A.; Puppala, A.J. Sustainability and geotechnical engineering: Perspectives and review. Can. Geotech. J. 2015, 52, 96-113. [CrossRef]

4. Pantelidou, H.; Nicholson, D.; Gaba, A. Sustainable Geotechnics. In ICE Manual of Geotechnical Engineering Volume 1: Geotechnical Engineering Principles, Problematic Soils and Site Investigation; ICE: London, UK, 2012; Volume 1, pp. 125-136. [CrossRef]

5. Egan, D.; Slocombe, B.C. Demonstrating environmental benefits of ground improvement. Proc. Inst. Civ. Eng.-Ground Improv. 2010, 163, 63-69. [CrossRef]

6. Fetherston, J. Comparing the Embodied Carbon and Local Environmental Impact of Common Geotechnical Foundation Solutions for the Australian Market. Australian Geotechnics Society-Victoria Symposium Proceedings. 2020. Available online: https: / / australiangeomechanics.org/downloads/victoria-symposium-proceedings/ (accessed on 28 July 2021).

7. Livesey, K.; Macé, E. The Challenge of Measuring and Mitigating the Environmental Performance of Foundations and Substructures Briefing Paper. BRE Briefing Paper. 2016. Available online: www.bre.co.uk (accessed on 28 July 2021).

8. Deamer, L.; Russell, E.; Lee, J. Lost in Translation: Sustainability down the Construction Supply Chain. ISO 20400: 2020. Available online: https:/ / www.iso20400.org/lost-in-translation-sustainability-down-the-construction-supply-chain/ (accessed on 28 July 2021).

9. Russell, E.; Lee, J.; Clift, R. Can the SDGs Provide a Basis for Supply Chain Decisions in the Construction Sector? Sustainability 2018, 10, 629. [CrossRef]

10. Abreu, D.G.; Jefferson, I.; Braithwaite, P.A.; Chapman, D.N. Why is Sustainability Important in Geotechnical Engineering? GeoCongress 2008 2008. [CrossRef]

11. Labuschagne, C.; Brent, A.; van Erck, R.P. Assessing the sustainability performances of industries. J. Clean. Prod. 2005, 13, 373-385. [CrossRef]

12. World Commission on Environment. Report of the World Commission on Environment and Development: Our Common Future towards Sustainable Development 2. Part II. Common Challenges Population and Human Resources 4; United Nations: Oxford, UK, 1987.

13. United Nations. The 17 Goals. Sustainable Development. 2021. Available online: https://sdgs.un.org/goals (accessed on 28 July 2021).

14. Scott, L.; McGill, A. Creating a Strategy for a Better World How the Sustainable Development Goals Can Provide the Framework for Business to Deliver Progress on Our Global Challenges. 2019. Available online: www.pwc.com/sdgchallenge (accessed on 28 July 2021).

15. GRI. Global Reporting Index. 2021. Available online: https://www.globalreporting.org/ (accessed on 28 July 2021).

16. GRI, UN Global Compact, and WBCSD. The Guide for Business Action on the SDGs. 2015. Available online: www.sdgcompass.org (accessed on 28 July 2021).

17. Collins. Collins English Online Dictionary. 2021. Available online: https://www.collinsdictionary.com/dictionary/english/ function (accessed on 28 July 2021).

18. Gilbert, G.N.; Stoneman, P. Researching Social Life, 4th ed.; Sage: London, UK, 2016.

19. Yin, R.K. Case Study Research and Design, 6th ed.; Sage: London, UK, 2018.

20. Cordeiro, J.; Filipe, J. Comparative Analysis of Ontology Charts and other Modelling Techniques. In Project Management and Risk Management in Complex Projects: Studies in Organizational Semiotics; Springer: Dordrecht, The Netherlands, 2007; pp. 145-163. [CrossRef]

21. Muir, I.; Langford, D. Managerial behaviour in two small construction organisations. Int. J. Proj. Manag. 1994, 12, $244-253$. [CrossRef]

22. Chen, X.; Lee, J. The Identification and Selection of Good Quality Data Using Pedigree Matrix. In Sustainable Design and Manufacturing; Springer: Singapore, 2020; pp. 13-25. [CrossRef]

23. Goubran, S. On the Role of Construction in Achieving the SDGs. J. Sustain. Res. 2019, 1. [CrossRef]

24. EcoInvent. EcoInvent Database 3.7. 2021. Available online: https:/ /www.ecoinvent.org/ (accessed on 28 July 2021).

25. Circular Ecology. Inventory of Carbon and Energy database V3. 2019. Available online: https:/ / circularecology.com/embodiedcarbon-footprint-database.html (accessed on 28 July 2021).

26. CSCS. Construction Skills Certification Scheme. 2021. Available online: https:/ /www.cscs.uk.com/ (accessed on 28 July 2021).

27. BRE. BREEAM. 2021. Available online: https://www.breeam.com/ (accessed on 28 July 2021).

28. USGBC. LEED Rating System. 2021. Available online: https:/ /www.usgbc.org/leed (accessed on 28 July 2021).

29. Mates in Mind. Mates in Mind. 2021. Available online: https://www.matesinmind.org/ (accessed on 28 July 2021).

30. Isham, A.; Mair, S.; Jackson, T. Wellbeing and Productivity: A Review of the Literature Item. CUSP Working Paper. 2020. Available online: http:/ / hdl.handle.net/10454/18268 (accessed on 30 July 2021).

31. Deamer, L.R.; Lee, J.J.; de Waele, J.E.; Mulheron, M.J.; France, C.M. How Does the Current System of Pre-Qualification Influence Sustainable Outcomes for the Geotechnical Industry? In Piling 2020; ICE Publishing: London, UK, 2021; pp. 529-534. [CrossRef] 
32. FORS. Fleet Operator Recognition Scheme Standard v5.1. 2020. Available online: https://www.fors-online.org.uk/cms/ (accessed on 28 July 2021).

33. European Parliament and Council. Directive 2012/19/EU on Waste Electrical and Electronic Equipment (WEEE); EU: Strasbourg, France, 2019.

34. Ranganathan, J.; Corbier, L.; Schmitz, S.; Oren, K.; Dawson, B.; Spannagle, M.; Mcmahon, M.; Boileau, P.; Frederick, R.; Vanderborght, B.; et al. The Greenhouse Gas Protocol: A Corporate Accounting and Reporting Standard; WBCSD: Geneva, Switzerland, 2004.

35. Rauter, R.; Jonker, J.; Baumgartner, R.J. Going one's own way: Drivers in developing business models for sustainability. J. Clean. Prod. 2017, 140, 144-154. [CrossRef] 